
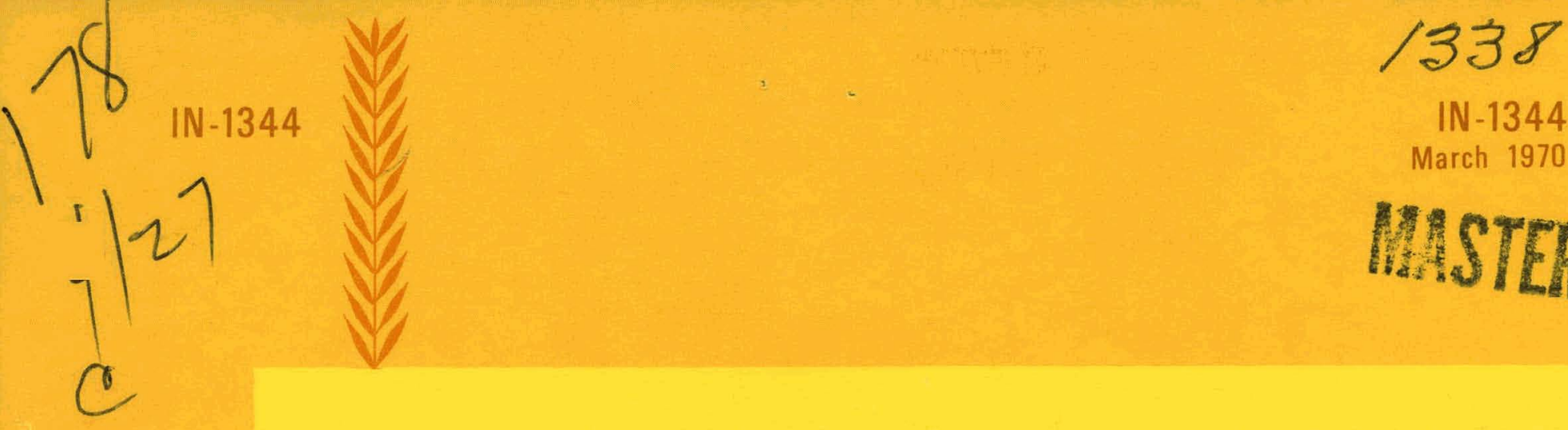

IN -1344

March 1970

\title{
MASTER
}

\section{SECOND PROCESSING CAMPAIGN IN THE WASTE CALCINING FACILITY}

by G. E. Lohse and M. P. Hales

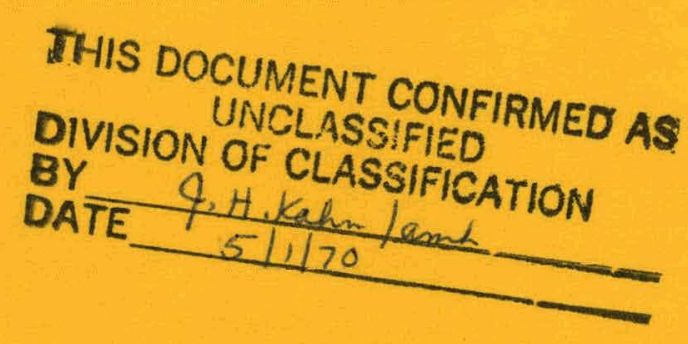

\section{IDAHO NUCLEAR CORPORATION} NATIONAL REACTOR TESTING STATION IDAHO FALLS, IDAHO P50030

\section{U.S. ATOMIC ENERGY COMMISSION}




\section{DISCLAIMER}

This report was prepared as an account of work sponsored by an agency of the United States Government. Neither the United States Government nor any agency Thereof, nor any of their employees, makes any warranty, express or implied, or assumes any legal liability or responsibility for the accuracy, completeness, or usefulness of any information, apparatus, product, or process disclosed, or represents that its use would not infringe privately owned rights. Reference herein to any specific commercial product, process, or service by trade name, trademark, manufacturer, or otherwise does not necessarily constitute or imply its endorsement, recommendation, or favoring by the United States Government or any agency thereof. The views and opinions of authors expressed herein do not necessarily state or reflect those of the United States Government or any agency thereof. 


\section{DISCLAIMER}

Portions of this document may be illegible in electronic image products. Images are produced from the best available original document. 
Printed in the United States of America

Available from

Clearinghouse for Federal Scientific and Technical Information

National Bureau of Standard.s, U. S. Department of Commerce

Springfield, Virginia 22151

Price: Printed Copy $\$ 3.00$; Microfiche $\$ 0.65$

\section{LEGAL NOTICE}

This report was prepared as an account of Government sponsored work. Neither the United States, nor the Commission, nor any person acting on behalf of the Commission:

A. Makes any warranty or representation, express or implied, with respect to the accuracy, completeness, or usefulness of the information contained in this report, or that the use of any information, apparatus, method, or process dlsclused in lhis tepuil may not infringe privatoly owned rights; or

B. Assumes any liabilities with respect to the use of, or for damages resulting from the use of any information, apparatus, method, or process disclosed in this repurt.

As used in the above, "person acting on behalf of the Commission" includes any employee or contractor of the Commission, or employee of such contractor, to the extent that such employee or contractor of the Commission, or employee of such contractor prepares, disseminates, or provides access to, any information pursuant to his employment or contract with the Commission, or his employment with such contractor. 
IN-1344

Issued: March 1970

Waste Disposal and Processing

TID-4500

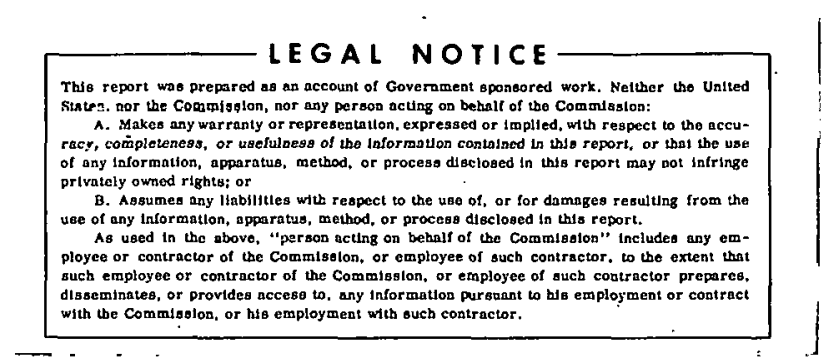

SECOND PROCESSING CAMDAIGN IN THE WASTE CALCINING FACILITY

BY

G. E. Lohse and M. P. Hales

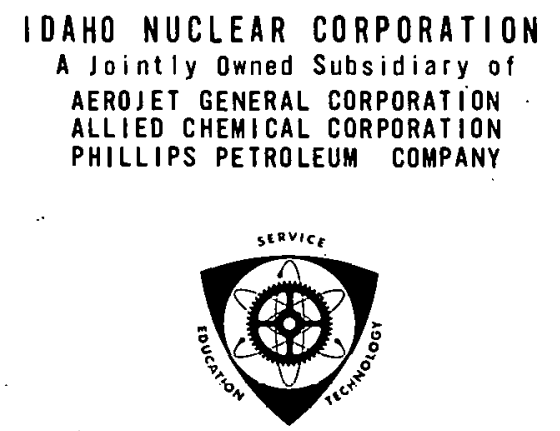

U. S. Atomic Energy Commission Research and Development Report Issued Under Contract AT(10-1)-1230

- Idaho Operations Office 


\begin{abstract}
For the first time, high-level radioactive zirconium fluoride wastes were calcined to solids in the Waste Calcining Facility as part of the second processing campaign. On this campaign which extended from April 1966 to March 1968, 880,000 gallons of aluminum fuel waste and 109,000 gallons of zirconium fuel waste were calcined in an air-fluidized bed heated to $400^{\circ} \mathrm{C}$ by means of a liquid metal heat transfer system. Calcination of the zirconium waste was a primary achievement because this waste contained substantial quantities of corrosive zirconium and aluminum fluorides. An overall operating on-stream time of $85.8 \%$ was achieved during the campaign. Decontamination of off-gas from the fluidized bed was excellent.
\end{abstract}




\section{SUMMARY}

Aqueous wastes resulting from the recovery of uranium from spent nuclear fuels routinely are converted to solids in the Waste Calcining Facility (WCF) at the Idaho Chemical Processing Plant (ICPP). In the second processing campaign which lasted from April 1966 to March 1968, 880,000 gallons of waste from aluminum alloy fuels and 109,000 gallons of waste from zirconium alloy fuels were calcined in an air-fluidized bed at $400^{\circ} \mathrm{C}$ to 11,250 and 1330 cubic feet of granular solids, respectively. Calcination of the zirconium fuel waste was particularly significant, as this was the first time this type of waste had been calcined on a production scale. This successful processing was the culmination of an extensive development program conducted at ICPP. During calcination, fluoride compounds were successfully contained in the solids and no fluoride contamination to the environment occurred.

Off-gas which consisted of fluidizing air, atomizing air, and waste decomposition products was successfully decontaminated in a series of air cleaning devices including a spray quench tower, a venturi scrubber and associated entrainment separators, silica gel adsorbers, and high-efficiency filters before being discharged to the atmosphere.

Significant results of the second processing campaign are summarized as follows:

(1) The net rates at which the waste solutions were converted to solids averaged 47.6 gallons per hour (gph) for zirconium fluoride waste and $67.1 \mathrm{gph}$ for aluminum waste. The zirconium fluoride waste required the addition of calcium nitrate solution for complexing corrosive fluoride ion and prevention of any significant fluoride volatilization.

(2) An on-stream operating factor of $85.8 \%$ was achieved during 714 days of operation, despite the fact that three major shutdowns occurred requiring decontamination of the calciner and/or associated equipment before repairs could be completed.

(3) The estimated bulk density of the solids was near $1.7 \mathrm{~g} / \mathrm{cc}$ for the zirconium fluoride waste and ranged between 1.0 and 1.2 grams per cubic centimeter $(\mathrm{g} / \mathrm{cc})$ for aluminum waste.

(4) No hazards resulted from direct discharge of the off-gas to the environment. Decontamination factors for particulate matter generally were about $10^{8}$ and were higher when processing zirconium waste than when aluminum waste was being processed. Decontamination for ruthenium was near $10^{5}$ and again was higher for the zirconium waste. Fluoride in the zirconium waste was successfully contained in the solids, and off-gas sample analyses showed fluoride concentrations below the detection limit (about $1 \times 10^{-8} \mathrm{~g} / \mathrm{cc}$ ). 
(5) The release rate of ${ }^{90} \mathrm{Sr}$ averaged near 0.1 millicurie/day, and that for ${ }^{106} \mathrm{Ru}$ averaged about seven millicuries/day; these are less than $0.1 \%$ of the established guide values for these isotopes. 


\section{CONTENTS}

ABSTRACT ....................... ii

I. SUMMARY......................... i i . .

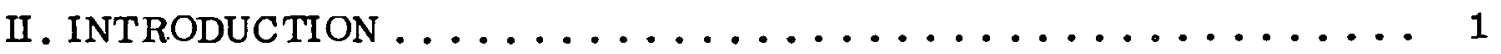

III. PROCESS EVALUATION ..................... 3

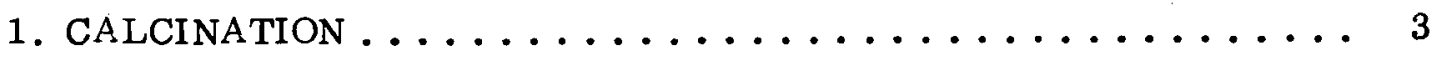

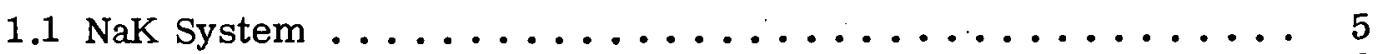

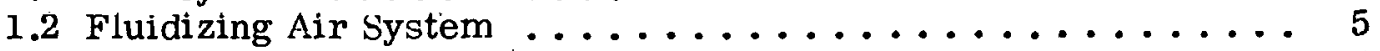

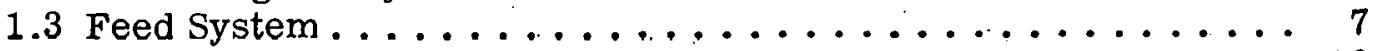

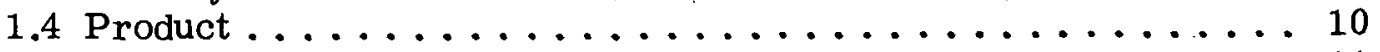

1.5 Product Transport System ....................... 11

2. OFF-GAS CLEANUP ........................ 13

2.1 Humidity Control and System Stoichiometry ........... 13

2.2 Particulate Solids Removal . . . . . . . . . . . . . . . . 14

2.3 Removal of Ruthenium .................... 14

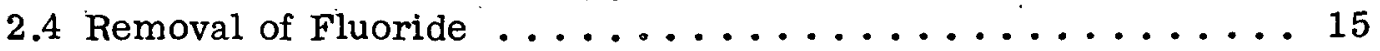

3. SPECIAL OPERATIONAL PERIODS ................. 16

3.1 Evaporation of Aluminum-Type Feed ... . . . . . . . . 16

3.2 Operation With Ammonium Nitrate Waste ............ 16

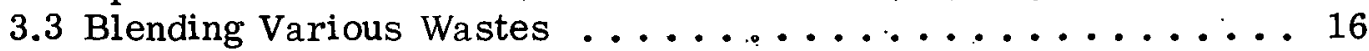

4. SOLIDS STORAGE ...................... 17

IV. UTILITIES AND E QUIPMENT PERFORMANCE . . . . . . . . . . . . . . 19

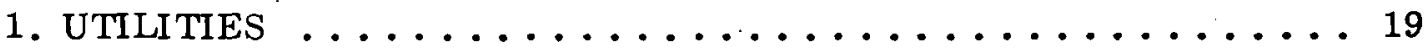

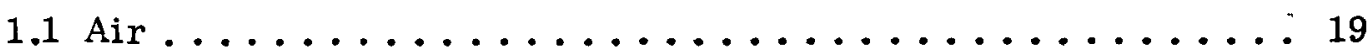

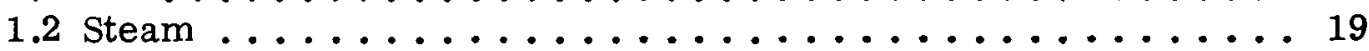

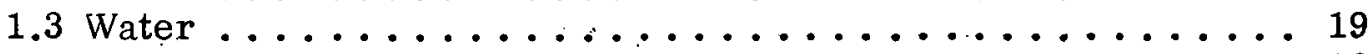

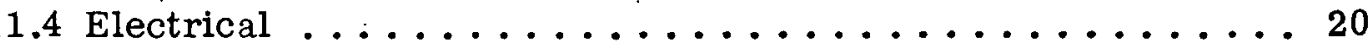

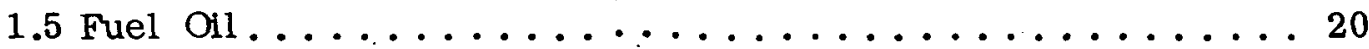

1.6 Service Waste System. . . . . . . . . . . . . 20

2. $\mathrm{NaK} \operatorname{SYSTEM} \ldots \ldots \ldots \ldots \ldots \ldots \ldots \ldots \ldots \ldots \ldots \ldots . \ldots \ldots \ldots$

2.1 Leaks in $\mathrm{NaK}$ Piping. . . . . . . . . . . . . . . . . 21

2.2 Failure of Heat Exchanger wC-302 .............. 23

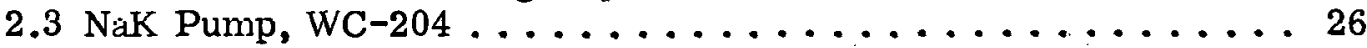

2.4 Oxide Removal System .................... 26 
3. MECHANICAL EQUIPMENT .................... 29

3.1 Fluidizing Air Blowers . . . . . . . . . . . . . . 30

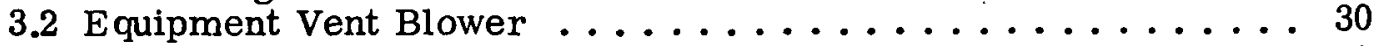

3.3 Main Off-Gas Blowers .................... 30

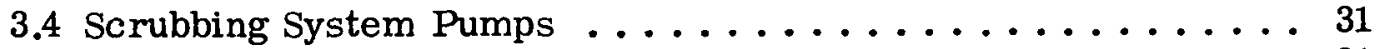

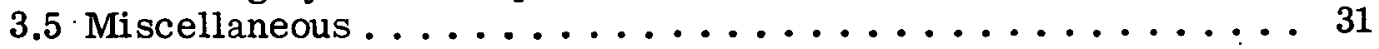

4. VALVES AND PIPING .................... 32

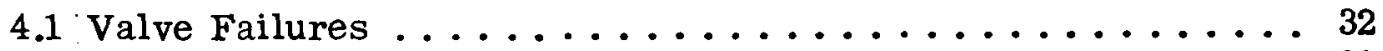

4.2 Piping Failures ......................... 32

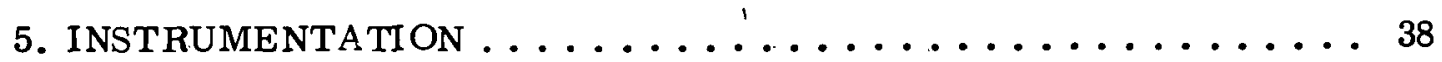

5.1 Temperature Measurement and Control . . . . . . . . . . . . 38

5.2 Feed Rate Measurement and Control . . . . . . . . . . . . . . 38

5.3 Measurements of Liquid Levels, Density, and Pressure . . . . . 39

5.4 Miscellaneous Instrument Problems . . . . . . . . . . . . 39

6. FILTERS............................ 40

6.1 Equipment Vent Filters ..................... 40

6.2 Main Off-Gas Filters ...................... 40

V. SHUTDOWN, DECONTAMINATION, AND INSPECTION ........ 42

1. SHUTDOWN AND DECONTAMINATION . . . . . . . . . . . 42

1.1 WCF Shutdown ........................ 42

1.2 WCF Decontamination .................... 43

2. FACILITY INSPECTION AND REPAIRS. . . . . . . . . . . 45

3. CONCLUSIONS ......................... 47

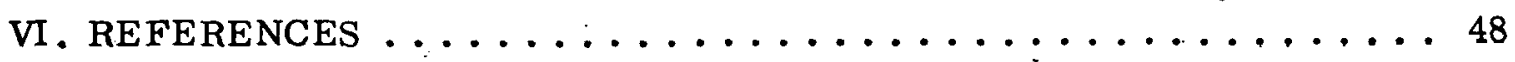

FIGURES.

1. Chronology of the second WCF processing campaign with radioactive aqueous waste ........................

2. WCF calciner vessel and auxiliary equipment. . . . . . . . . . . 4

3. Schematic flowsheet of the fluidized bed calcination process . . . . . 6

4. Effect of $\mathrm{Ca} / \mathrm{F}$ mole ratio on fluoride volatilization . . . . . . . . . 11

5. Performance of the off-gas cleanup system .............. 15 
6. WCF solids storage bins $\ldots \ldots \ldots \ldots \ldots \ldots \ldots \ldots \ldots \ldots$

7. NaK system flow diagram . . . . . . . . . . . . 22

8. Fluidized bed NaK heat exchanger . . . . . . . . . . 24

9. NaK heat exchanger details . . . . . . . . . . . . . 25

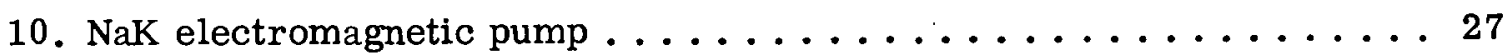

11. Transport air system. . . . . . . . . . . . . . 35

12. Calciner cell after product takeoff leak. . . . . . . . . . 36

13. Simplified flow sheet of the WCF solids storage bins . . . . . . . 37

\section{TABLES}

I. Typical Compositions of Radioactive Wastes .......... 8

II. Typical Calciner Operating Conditions . . . . . . . . 9

III. Typical Properties of Primary Product from Calciner . . . . . . . 12

IV. Performance of Waste Calcining Facility While Calcining

Zirconium Wastes ..................... 15

V. Incidents of NaK Pump Failure $\ldots \ldots \ldots \ldots \ldots \ldots \ldots \ldots$

VI. WCF Mechanical Equipment $\ldots \ldots \ldots \ldots \ldots \ldots \ldots \ldots \ldots$

VII. Valve Failures .................... 33

VIII. WCF Final Filter Replacement Data . . . . . . . . . . 41 


\section{INTRODUCTION}

The Waste Calcining Facility at the Idaho Chemical Processing Plant is the world's first production facility for converting high-level radioactive aqueous waste to solids[1]. First cycle solvent-extraction wastes from the recovery of uranium from spent nuclear fuels are sprayed into a hot, airfluidized bed of granular solids where water flashes off and metallic salts are converted to their corresponding oxides or fluorides.

Operation of the WCF with radioactive waste was begun in 1963 and this first campaign extended over 312 days. During that run, about 512,000 gallons of waste were calcined to 7350 cubic feet of solids, and on-stream time exceeded $99 \%$. Only wastes from the reprocessing of high-enriched aluminum-uranium alloy fuels were processed during the first campaign.

The second processing campaign, the subject of this report, ran from April 1, 1966 through March 24, 1968. A summary of this operation is presented graphically in Figure 1. In this campaign, about 880,000 gallons of aluminum-type waste and 109,000 gallons of zirconium fluoride-type waste were converted to about 11,250 and 1400 cubic feet of granular solids, respectively. Despite the fact that three major shutdowns occurred which required decontamination of the calciner and/or associated equipment before repairs could be completed, an on-stream time of $85.8 \%$ was realized through the 714 days of operation. Many notable achievements were experienced; the most noteworthy were the successful calcination of the high fluoride-bearing waste and the calcination of blends of different concentrations and compositions of aluminum wastes. This was the first campaign in which high fluoride-bearing wastes resulting from the processing of zirconium alloy fuels have been calcined on a production scale; this feat represents the culmination of an extensive development program, the results of which are reported elsewhere[2].

The purpose of this report is to describe the WCF operation during this second campaign, with particular emphasis on the calcination of the fluoridebearing waste. 


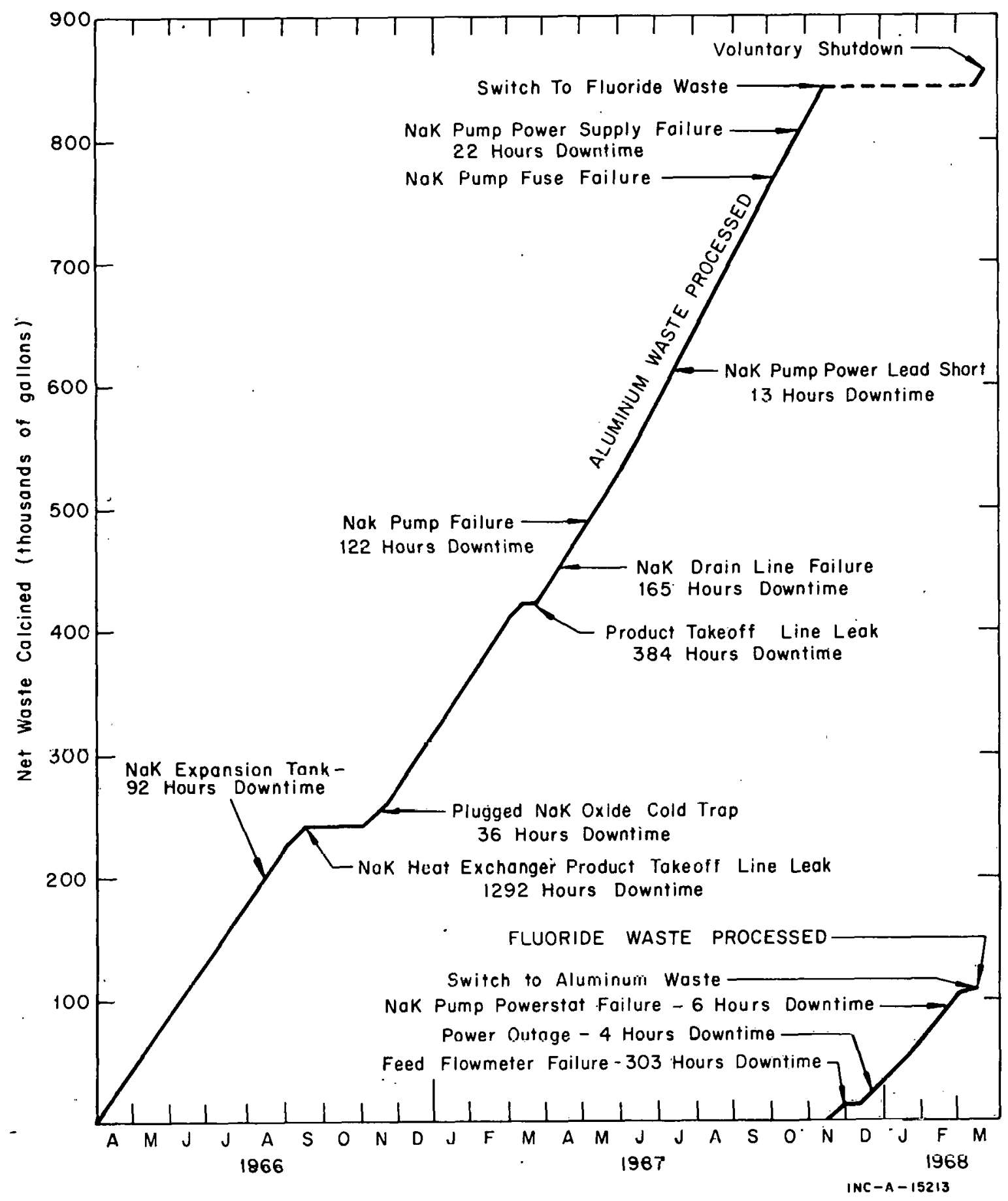
FIG CHRONOLOSOG OF THE SECOND WCF PROCESSING CAMPAIGN WITH RADIOACTIVE
AQUEOS 


\section{PROCESS EVALUATION}

The WCF converts aqueous radioactive wastes to solids in a fluidized bed calciner. In the process, the solids are transferred to underground storage bins while the water vapor is carried to the environment with the fluidizing and atomizing gases. The WCF, therefore, contains equipment which directly or indirectly supports three functions: calcination of the waste, storage of the solid residue, and off-gas cleanup. The evaluation of these functions is presented in sections which follow.

\section{CALCINATION}

The heart of the facility is the four-foot diameter fluidized bed calciner shown in Figure 2. Radioactive waste solutions are injected through pneumatic atomizing nozzles into a heated $\left(400^{\circ} \mathrm{C}\right)$ bed of granular solids that is fluidized with air. The feed (waste solution generated during reprocessing of aluminumuranium or zirconium-uranium alloyed fuel elements and with a full range of aged fission products) is divided equally among three nozzles and flows at a nominal total rate of 85 to 100 gallons per hour. This feed rate includes batch recycle of off-gas scrubbing solution at a rate of 15 to 30 gallons per hour.

The volumetric ratio of atomizing air to liquid feed is varied as necessary to cause sufficient breakup of bed particles and thereby control the average bed particle size at the desired value. The value of this volumetric ratio varies from 500 to 600 when calcining aluminum-type waste to 700 to 800 when calcining zirconium-type waste. The bed level is maintained above the feed spray zone at all times so that the spray contacts bed particles in a fluidized state. Heat is supplied to the fluidized bed by an internal heating bundle through which sodium-potassium eutectic alloy $(\mathrm{NaK})$ is circulated at temperatures up to $760^{\circ} \mathrm{C}$. The NaK is pumped by an electromagnetic pump and heated by an oil-fired furnace. Preheated fluidizing air is introduced through 14 orifices equally spaced in the air distribution plate. Each orifice is surmounted by a cap that helps to distribute the air more uniformly in the bed and to minimize backflow of solids when the flow of fluidizing air is stopped. Operation at a superficial fluidizing velocity between 1.0 and 1.3 feet per second has been satisfactory over the usual average bed-particle size range of 0.6 to $0.75 \mathrm{~mm}$. This size range was chosen as the best compromise between the diametrically opposed considerations of small size to give high heat transfer rates and larger size to minimize rates of elutriation of solids from the bed. A louvered baffle in the overhead space of the calciner was installed to deflect particles back to the bed because insufficient disengaging space exists in the vessel for adequate de-entrainment by purely gravitational forces.

Thermal decomposition of the nitrate and fluoride salt solutions to metallic oxides and fluorides, water vapor, and nitrogen oxides are the principal reactions occurring during calcination. Solid product builds up in layers on the bed particles, while the gaseous products are swept from the vessel with the fluidizing gases. A stable bed level is maintained by adjusting the rate of product removal. Average size of the bed particles is controlled through the creation of seed particles, primarily by breakup of the bed particles by the high velocity feed atomizing air stream. 


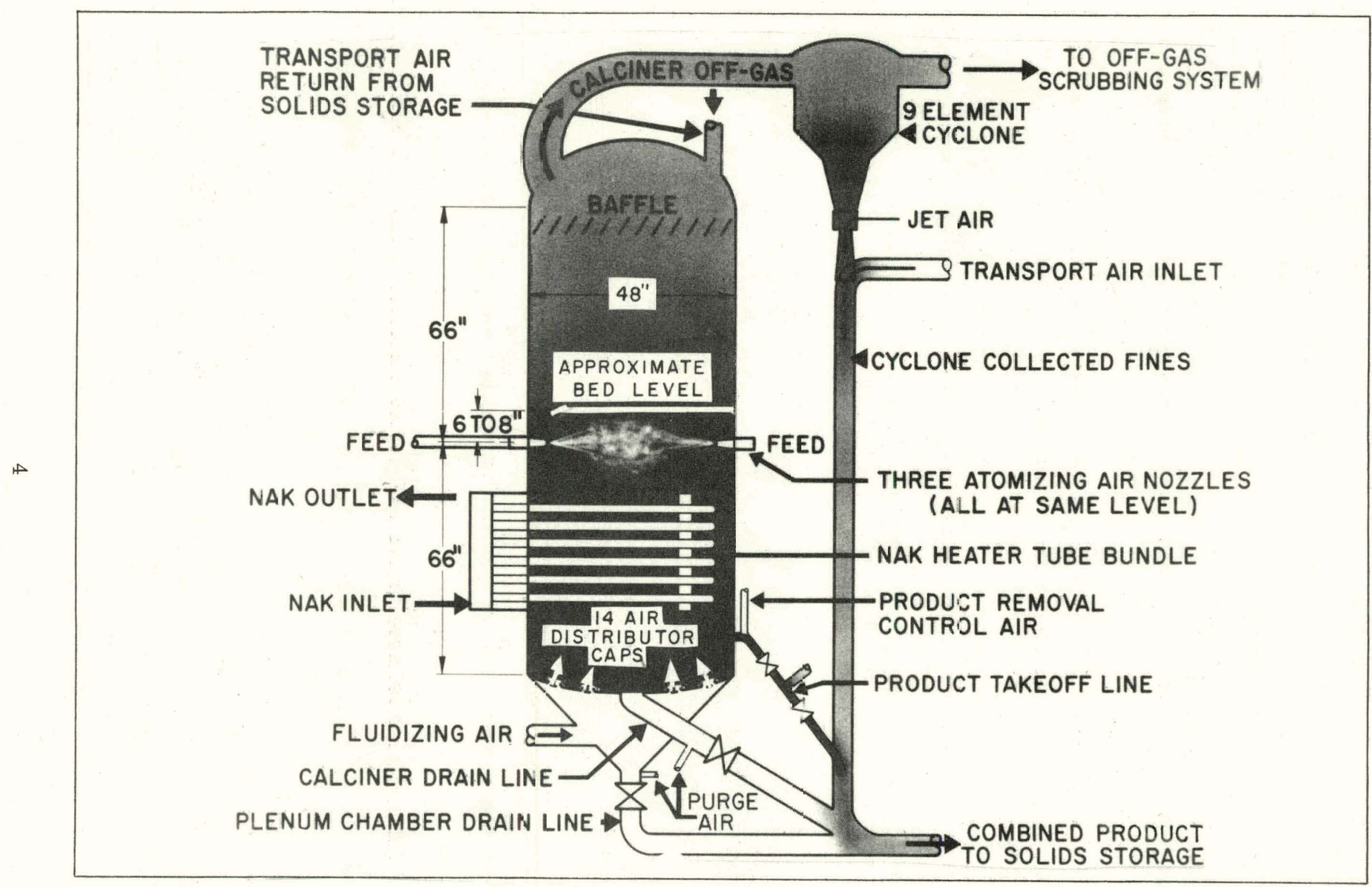

FIG. 2 WCF CALCINER VESSEL AND AJXILIARY EQUIPMENT. 
Solid product is transported from the calciner to the storage bins from two sources by means of a pneumatic transport system. About $60 \%$ of the product is removed from the bottom of the calciner through the takeoff line connecting the calciner and the product transfer system. Dilution air, added to the takeoff line near the junction with the calciner, regulates the rate of product withdrawal; the product rate varies inversely with the dilution air flow rate. About $40 \%$ of the product is elutriated from the calciner with the off-gas and is separated from this gas in the calciner cyclone. These solids are transferred by air jet into the solids transport line where they combine with the solids removed from the bottom of the calciner. The product is transported to a second cyclone above the storage bins where it is separated from the transport air. The solids fall by gravity into the bins, and the transport air is returned to the overhead space of the calciner to be decontaminated with the process off-gas. Since no other motive force is normally applied, the driving force for the transfer system is limited by the pressure drop between the product takeoff point and the top of the calciner where the transport gas reenters.

In the following subsections of this report, the purpose and operating performance of each of these calcination systems will be discussed. Detailed designs will not be discussed, as these are presented elsewhere[3].

\section{$1.1 \mathrm{NaK}$ System}

The heat required for decomposition of the calciner feed was supplied through an indirect heat-transfer system depicted schematically in the WCF process flowsheet shown in Figure 3. The eutectic mixture of sodium and potassium ( $\mathrm{NaK}$ ) was pumped through a three-inch stainless steel pipe to an oil-fired furnace where the temperature was raised to a maximum of $760^{\circ} \mathrm{C}$, past expansion tanks which allowed for an increase of $25 \%$ in the cold volume, to the fluidized bed heater where it gave up heat and was cooled approximately $115^{\circ} \mathrm{C}$, then back to the pump. The NaK flow was normally kept at a constant rate of about 45,000 pounds per hour by manual adjustment of the power input to the electromagnetic pump. During the run, the system was started up from room temperature nine times and operated for 15,420 hours above $600^{\circ} \mathrm{C}$ and 545 hours below $600^{\circ} \mathrm{C}$. At the completion of this run, totals on this system since its initial operation in 1961 were 48 startups, 27,229 operating hours above $600^{\circ} \mathrm{C}$, and 1381 operating hours below $600^{\circ} \mathrm{C}$.

In general, operating parameters and performance of this liquid metal system are independent of the type of waste being calcined. Gencrally the temperature of the NaK leaving the oil-fired furnace was maintained between 710 and $740^{\circ} \mathrm{C}$. The waste feed rates were increased or decreased to keep within this operating range.

\subsection{Fluidizing Air System}

Air for fluidizing the calciner bed was pumped from one of two positivedisplacement blowers through a metering orifice and control valve to an air coil in the top of the $\mathrm{NaK}$ furnace where it was heated to $400^{\circ} \mathrm{C}$ before being introduced into the calciner vessel. The heated air passed through 14 distributor caps[3] mounted on the bed support plate. These caps are of a novel design developed to greatly reduce erosion of the caps as well as to provide adequate pressure drop across the distributor plate and are described elsewhere. 


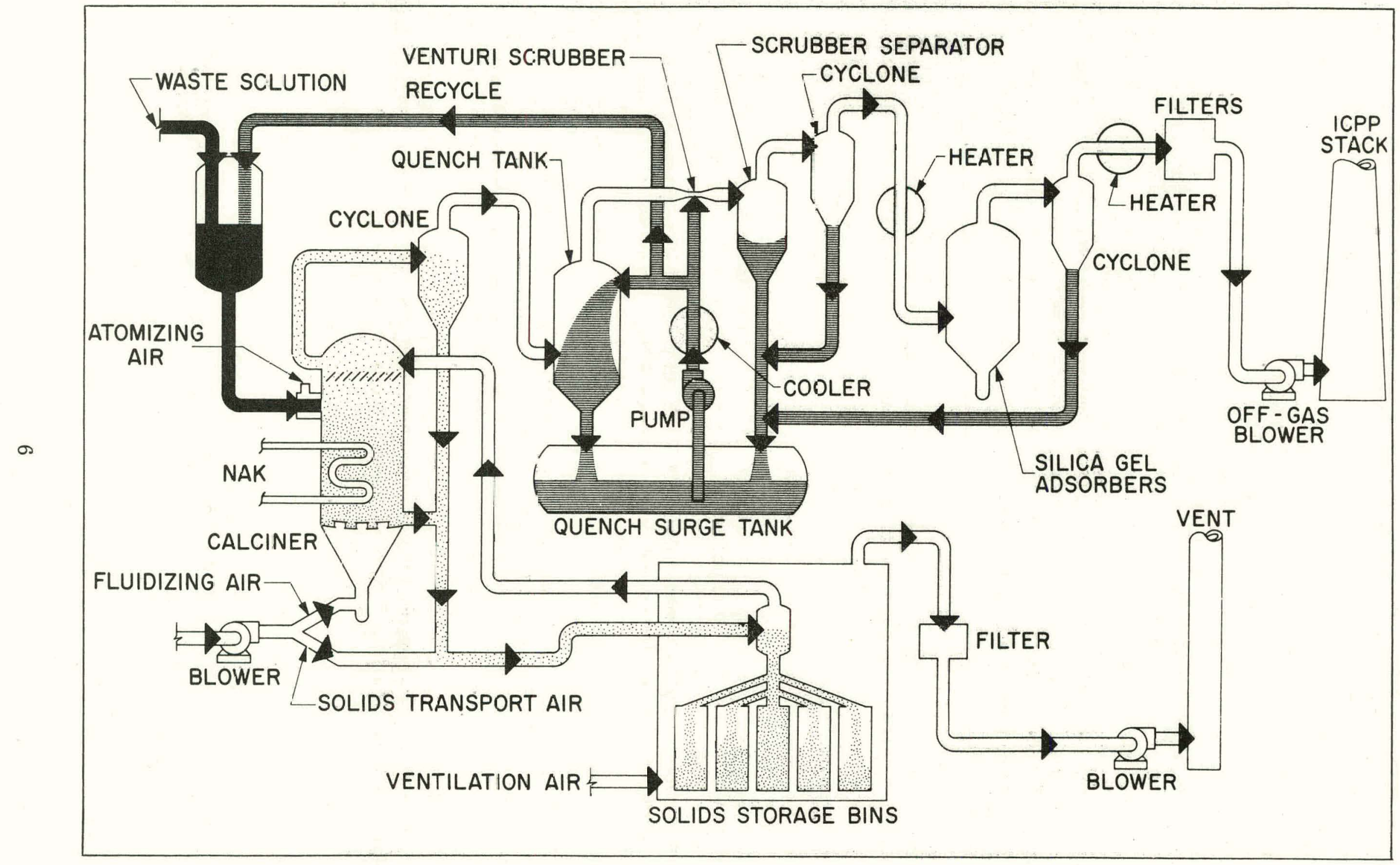

Fig. 3 SCHEMATIC = LOWSHEET OF THE FLUIDIZED BED CALCINATION PROCESS. 
Control of the fluidizing air was adequate throughout the campaign. Changes recommended[1] and accomplished prior to startup satisfactorily eliminated previous adjustments necessary because of pressure pulsations on the flow transmitter from alternate blower operation. The type of waste processed had no effect, per se, on the system performance. However, because of changes in the mean particle size and in the bulk density of bed, it was necessary to increase the superficial fluidizing velocity when calcining zirconium waste. For aluminum waste processing, the superficial fluidizing velocity was maintained near 0.9 foot per second and the pressure drop across the bed support plate was about 17 inches of water, or about $25 \%$ of the total calciner pressure drop. For zirconium waste processing the superficial fluidizing velocity was maintained near 1.3 feet per second and the pressure drop across the bed support plate was about 28 inches of water, or about $28 \%$ of the total calciner pressure drop. About 10 to $13 \%$ of the total fluidizing air was introduced through the calciner sparge ring above the bed support plate.

Temperatures at the bottom, center, and top of the fluidized bed were used for indicating adequacy of fluidization. Normally, these temperatures were within a $10^{\circ} \mathrm{C}$ spread, and variations outside this range indicated that an increase in fluidizing velocity was necessary. Usually, these adjustments were accomplished easily by increasing the volume of air introduced through the calciner sparge ring.

\subsection{Feed System}

Waste feed to the calciner was controlled by three remotely operated throttling valves actuated by pneumatic controllers which received signals from electromagnetic flow transmitters installed upstream of the valves. The feed was sprayed into the fluidizing bed through three pneumatic-atomizing spray nozzles. The average gross feed rates achieved during the campaign were 92.9 gallons per hour (gph) for aluminum waste and $89.1 \mathrm{gph}$ for zirconium fluoride waste. The net rates were $67.1 \mathrm{gph}$ for aluminum waste and 47.6 for zirconium fluoride waste and the recycle rates were 25.8 and $25.1 \mathrm{gph}$, respectively. For the zirconium fluoride waste about $16.4 \mathrm{gph}$ of saturated calcium nitrate solution was added for complexing the fluoride ion in the feed.

The gross feed to the calciner originated from two sources: the first from the liquid waste tank plus dilution from steam jet transfer (jet dilution averaged about 5\%); the second from the off-gas scrubbing solution. The solutions were transferred batchwise to the calciner waste hold tanks at the approximate ratio of three volumes of waste to one volume of scrubbing solution.

Average compositions of the high-level waste solutions fed to the WCF are given in Table I. These waste solutions (resulting from chemical processing of nuclear fuels) are usually stored from two to five years in stainless steel tanks located in underground concrete vaults prior to calcination. The concentrations of the significant radionuclides and heat generation for the solutions are included in the table. Principal operating conditions for the WCF are shown in Table II.

The boric acid included in the feed composition as listed in Table I was added batchwise to the aluminum feed solution after transfer to the WCF to 
TYPICAL COMPOSITIONS OF RADIOACTIVE WASTES

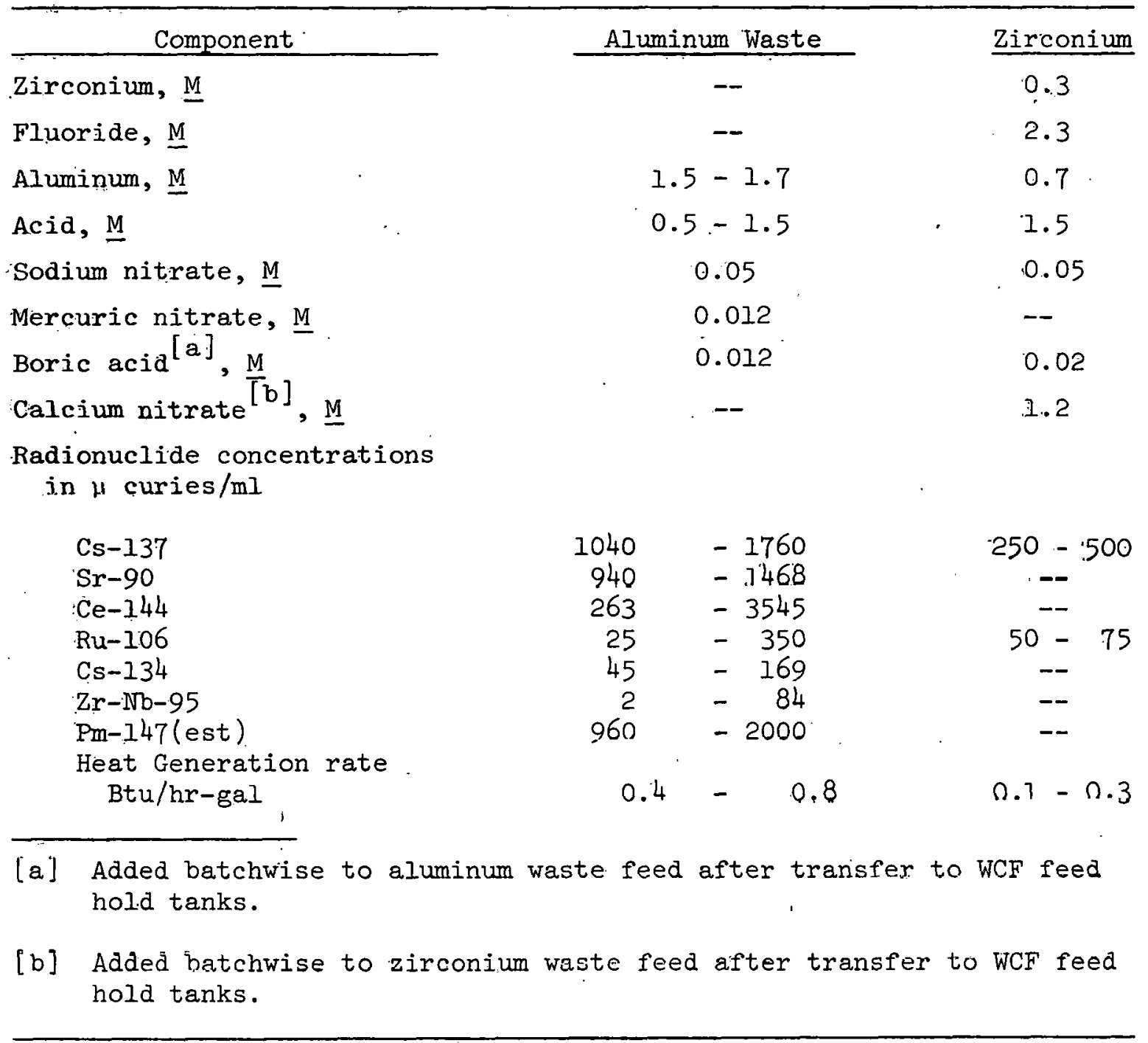

suppress the formation of the undesired alpha form of alumina and thus ensure that the product was essentially amorphous alumina. Amorphous alumina is soluble in dilute nitric acid and is less abrasive, yet more resistant to attrition, than the alpha form. Thus, with amorphous alumina product, off-gas cleanup and system decontamination problems are minimized; and erosion of pumps, valves, and lines in the off-gas scrubbing system is less than with the alpha alumina.

The calcium nitrate solution included with the fluoride-bearing zirconium waste solution was added batchwise after transfer of the feed to the WCF to suppress the formation of volatile fluorides during calcination. If allowed to form, the volatile fluorides would greatly increase the corrosion rates of the process equipment. Based on operation of the pilot plant calciner, the required calcium-to-fluoride mole ratio was established at 0.5 ; this amount of calcium 
TYPICAL CALCINER OPERATING CONDITIONS

Feed Rates:
Gross to calciner, gph
Recycle to calciner, gph
Calcium nitrate, gph
Net to calciner, gph
Product Rate:
To solids storage, lb/hr
Calciner Conditions:
Superficial fluidizing velocity,
ft/sec
Volume ratio of nozzle air to feed
rate
Bed temperature, ${ }^{\circ} \mathrm{C}$
NaK inlet temperature, ${ }^{\circ} \mathrm{C}$
Bed height, in.
Mass median bed particle diameter,
mm

\begin{tabular}{cll} 
Aluminum Waste & & \multicolumn{2}{l}{ Zirconium Wa } \\
\hline $85-100$ & & $85-100$ \\
$15-30$ & $15-30$ \\
-- & $20=30$ \\
$60-80$ & $45-55$
\end{tabular}

$50-55 \quad 80-90$

Scrubbing System:

Sollds entering scrubbing system, $\mathrm{lb} / \mathrm{hr}$

$\begin{array}{llll}1.0 & 1.3 \\ 515 & -660 & 650 & -800 \\ 400 & & 400 & \\ 690 & -735 & 690 & -735 \\ 73 & & 73\end{array}$
Aluminum, $\underline{\mathrm{M}}$ Acid, $\underline{M}$

Undissolved solids, $\mathrm{g} / \mathrm{l}$

Scrubbing solution rate to quench tower, gpm

Pressure drop across quench tower, in. $\mathrm{H}_{2} \mathrm{O}$

scrubbing solution rate to venturi scrubber, gpm
$0.5-$
0.8
$0.6-$
0.8

Pressure drop across venturi scrubber, in. $\mathrm{H}_{2} \mathrm{O}$

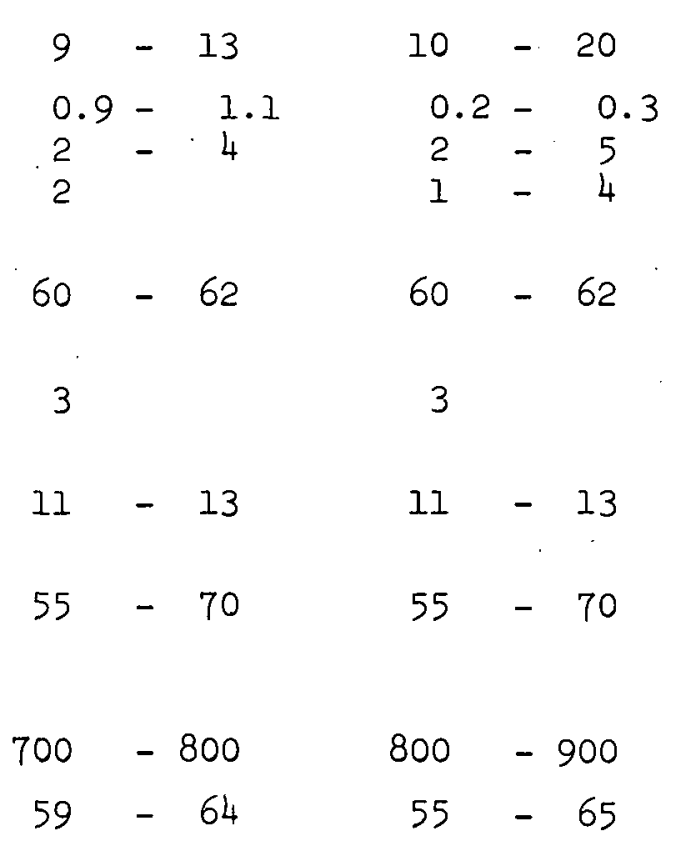

Ruthenium Adsorption and Filtering:

Total gas flow, scfm

Dew point of gas, ${ }^{\circ} \mathrm{C}$ 
TABLE II (Contd.)

TYPICAL CALCINER OPERATING CONDITIONS

\begin{tabular}{|c|c|c|c|c|c|c|}
\hline Ruthenium Adsorption and Filtering: & \multicolumn{2}{|c|}{ Aluminum } & Waste & Zirc & nium & Waste \\
\hline Adsorber operating temperature, ${ }^{\circ} \mathrm{C}$ & 66 & - & 74 & 65 & -7 & 70 \\
\hline $\begin{array}{l}\text { Pressure drop across adsorbers, } \\
\text { in. } \mathrm{H}_{2} \mathrm{O}\end{array}$ & 6 & - & 9 & 6 & & 9 \\
\hline $\begin{array}{l}{ }^{\circ} \mathrm{C} \\
{ }^{\circ} \text { filter operating temperature, }\end{array}$ & 80 & - & 85 & 80 & & 85 \\
\hline $\begin{array}{l}\text { Pressure drop across final filters } \\
\text { and adjacent piping, in. } \mathrm{H}_{2} \mathrm{O} \text {. }\end{array}$ & 5 & - & 12 & 5 & -1 & 12 \\
\hline
\end{tabular}

addition essentially eliminated any fluoride volatilization. The percent fluoride volatilized during calcination as a function of the calcium/fluoride ratio is shown in Figure 4. During operation of the WCF, $10 \%$ excess calcium -- ie, a calcium/fluoride ratio of 0.55 - - was added to ensure adequate suppression of the fluoride volatility. Although the addition of the calcium nitrate to the zirconium feed converted the solution to a thin slurry, no significant feed control problems were encountered on the campaign.

\subsection{Product}

The calcined product from the WCF was granular, largely spherical solids and consisted of two portions -- that removed directly from the bottom of the bed and that collected by the primary cyclone. Neither of these streams could be sampled; therefore, the rates and analyses of each are not available. However, previous pilot plant development work has shown no significant difference in composition of material in these streams. Samples were removed from the fluidized bed and analyzed routinely for determining product chemical and physical properties. Typical properties for both aluminum-type and zirconiumtype wastes are shown in Table III.

Slight varlations in compositions of the waste calcined were due to the wide variety of nuclear fuels processed at the ICPP. The composition of the zirconium waste solids reflects the large percentage of calcium which was added to the waste prior to its calcination to complex the fluoride ion. X-ray analysis of the solids product indicated that the primary cystalline species were fluorite $\left(\mathrm{CaF}_{2}\right)$ and tetragonal zirconium dioxide. The remaining species were amorphous. For aluminum waste, the solids product usually was amorphous, though occasionally the gamma form of alumina was detected.

The particlc sizc of the bed was controlled by adjusting the nozzle air-toliquid volume ratio (NAR) to provide adequate particle breakup to form necessary new seed particles. The normal operating value of NAR for aluminum waste necessary to control the mass median particle diameter to near 0.6 millimeter was 600; this value for zirconium waste was about 740 . The particle size for the zirconium fluoride bearing waste stabilized near about 0.7 millimeter. 


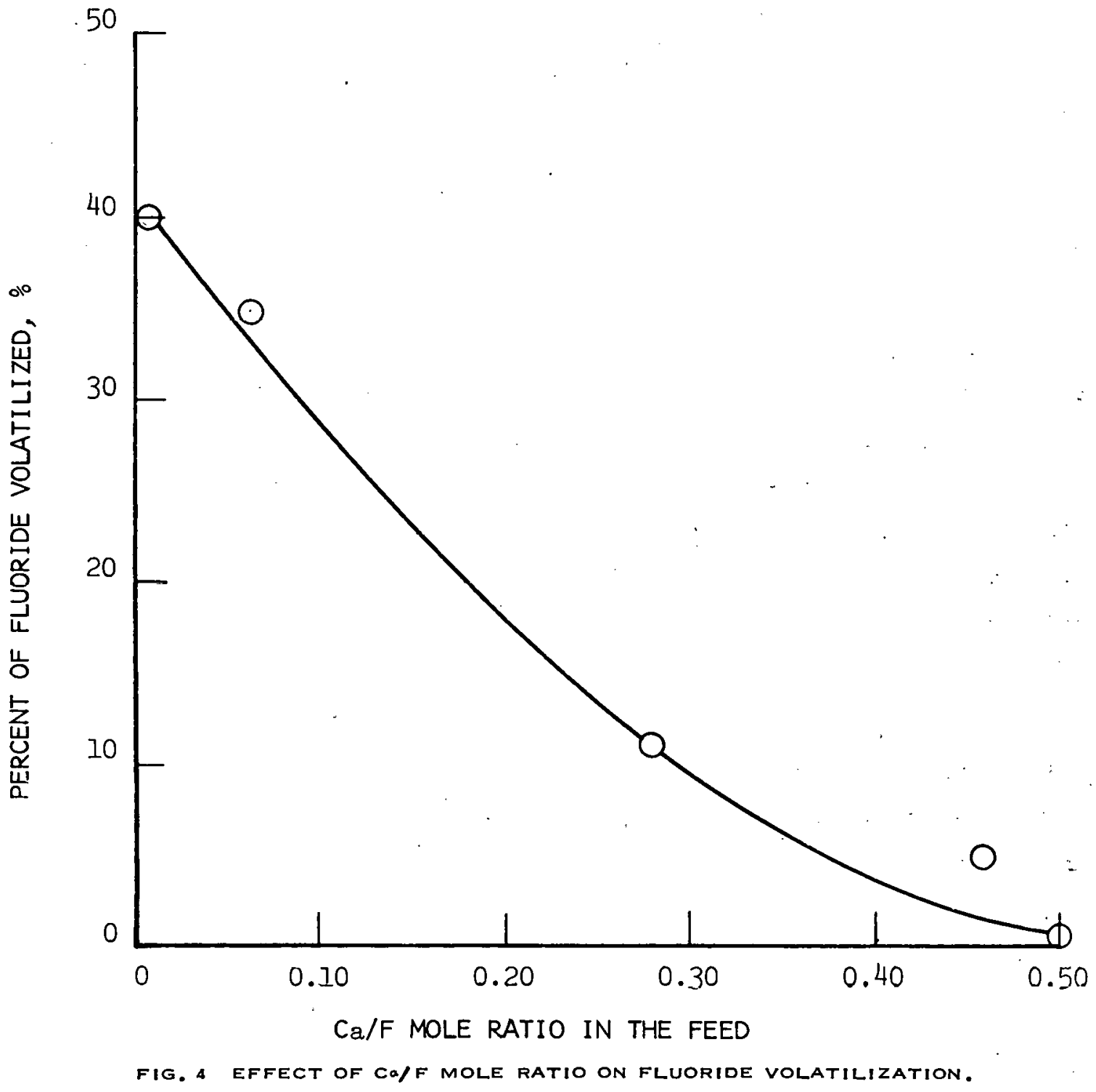

\subsection{Product Transport System}

As mentioned previously, the solids transferred to storage originated from two sources, those from the calciner cyclone and those from the bottom of the calciner bed. Both product streams combined below the calciner from whence they were transported pneumatically to a cyclone located above the solids storage bins. There the bulk of the solids was removed and fell by gravity to the bins. The air, which contained a small amount of very fine dust, was returned to the top of the calciner to be decontaminated with the process off-gas. The motivating force for the solids transport was provided by the calciner vacuum, with the maximum limited by the pressure drop across the bed during usual operation. Air from the fluidizing air blower was reduced to below atmospheric pressure by a throttling valve which was actuated from a pressure controller in the transport line downstream of the calciner. This air flowed through a heater where its temperature was raised to 100 to $120^{\circ} \mathrm{C}$, then past the bottom of the cyclone hopper where solids were transferred into the line by means of an air jet (the pressure in the cyclone was lower than the pressure 
TABLE III

TYPICAL PROPERTIES OF :PRIMARY PRODUCT FROM CALCINER

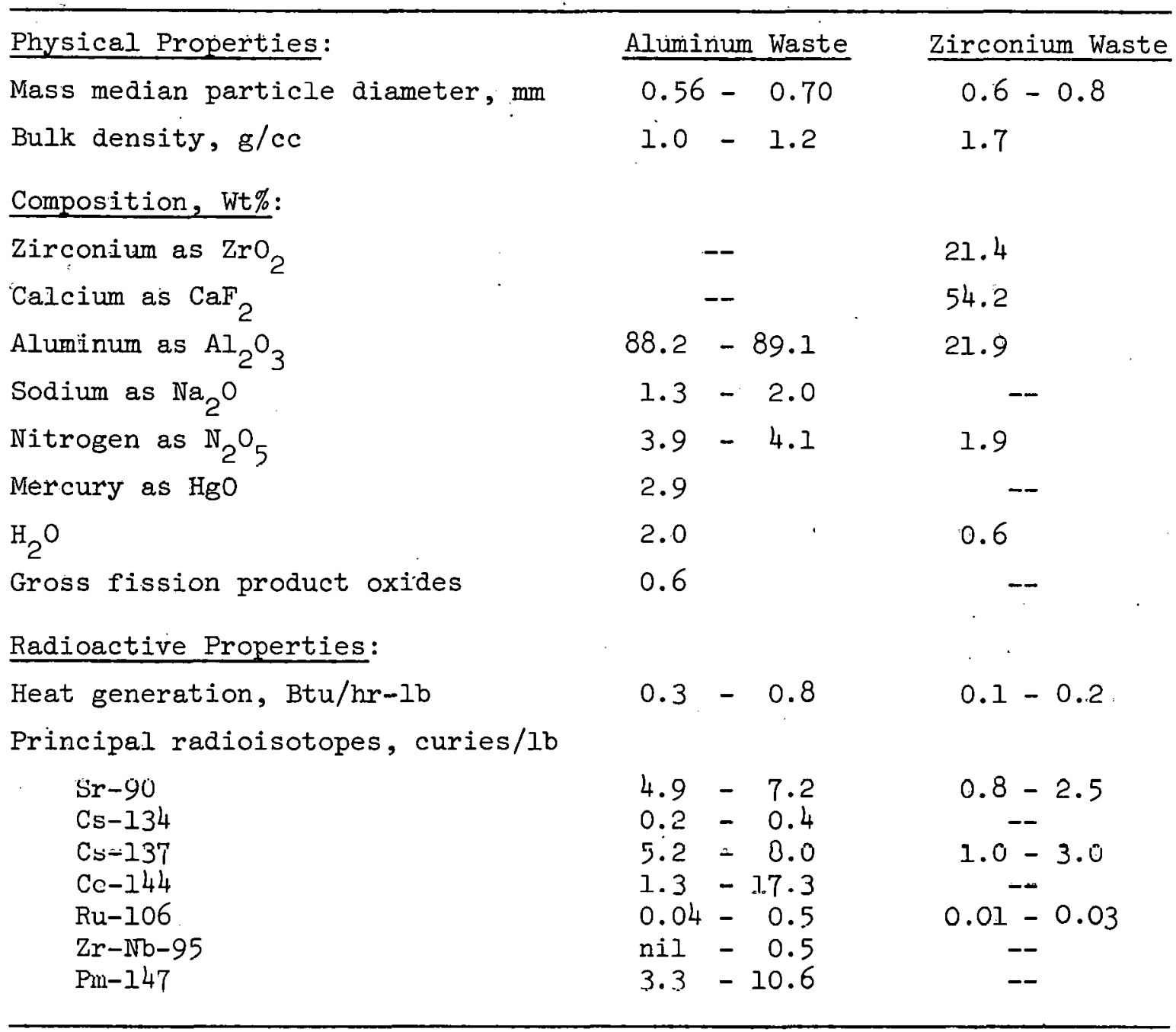

in the transport line), then below the calciner where solids from the calciner bed were conveyed into the line by special product takeoff piping, then to the solids storage cyclone.

- In general, the product transfer system operated smoothly throughout the campaign, and bed-level control was satisfactory. Some erosion (see Section IV-4.2) was encountered which forced shutdown for repairs. These situations were mechanical in nature and were corrected by mechanical means, ie, redesign of components. On the other hand, certain malfunctions with the product takeoff system were encountered during processing with zirconium fluoride waste, which appeared to be attributable to process variations. At times, inadequate control of bed removal prevented proper bed level in the calciner vessel, and variation of the usual withdrawal parameters would not produce the desired change. Alternate methods (withdrawal through "shutdown" valives and variations in the fluidizing air rate) were used to continue operation of the WCF and thus circumvent these undesirable occurrences. The more 
successful of the alternate methods employed appeared to be variations in fluidizing air rate to cause better operation of the product takeoff system. Clearly, more experimentation to define parameters affecting the product takeoff system is required.

\section{OFF-GAS CLEANUP}

A major portion of equipment in the WCF serves for decontamination of the calciner off-gas which contains both particulate matter and volatile species of matter which must not be released to the environment. The particulate matter is removed primarily in a wet scrubbing system (consisting of a spray quench tower and a venturi scrubber) and by high-efflciency particulate air (HEPA) filters. The volatile species of matter are removed in the wet scrubbing system (by chemical reaction with scrubbing solution components) and by adsorption of silica gel. A discussion of the performance of the various off-gas cleaning components follows.

\subsection{Humidity Control and System Stoichiometry}

One function of the WCF off-gas is to carry the water and nonradioactive gaseous materials from decomposition of the feed to the atmosphere. During the run approximately $80 \%$ of the water in the gross amount of solution fed to the calciner was removed with the off-gas by adjusting the gas humidity. The remaining $20 \%$ was condensed and used to scrub particulate matter from the off-gas in the scrubbing system and to control the off-gas temperature. This solution was recycled back into the feed system. The off-gas left the calciner cyclone at a temperature near $300^{\circ} \mathrm{C}$ and was cooled to 70 to $75^{\circ} \mathrm{C}$ by scrubbing solution sprayed countercurrently to the off-gas by four pressure-atomizing nozzles as it passed through the quench tower. The gas then entered the venturi scrubber and was cooled an additional $10^{\circ} \mathrm{C}$ as it contacted scrubbing solution. Through control of the scrubbing-solution temperature, the rate of condensation ( $20 \%$ of the condensibles in the off-gas leaving the top of the calciner vessel) was established to maintain the concentration of the largely soluble solids in solution at a level safely below saturation; the rate of recycle of this solution to the feed thus was set equal to the condensation rate.

The scrubbing solution was recirculated through the scrubbing system and was eventually recycled to the feed tank by a vertical, centrifugal pump. The flow rate of scrubbing solution to the quench tower averaged 230 liters $/ \mathrm{min}$ $(61 \mathrm{gpm})$ at a temperature of 60 to $65^{\circ} \mathrm{C}$. The flow rate to the venturi scrubber averaged 46 liters $/ \mathrm{min}(12.2 \mathrm{gpm})$ at a temperature of 60 to $65^{\circ} \mathrm{C}$. The scrubbing solution was cooled from about 65 to $70^{\circ} \mathrm{C}$ to 60 to $65^{\circ} \mathrm{C}$ as it passed through a water-cooled heat exchanger, WC-307.

In order to prevent condensation in the off-gas lines or vessels downstream of the venturi scrubber, the gas was Isuperheated usually from 5 to $10^{\circ} \mathrm{C}$ in a steam-heated shell and tube heat exchanger. This temperature difference was automatically maintained by "feeding" the output of an electronic controller for the temperature upstream of the heat exchanger to the setpoint of the heat 
exchanger steam controller. The setpoint was based on the temperature differential desired above the input signal temperature. The controlled off-gas temperature was normally within $\pm 1^{\circ} \mathrm{C}$ of the setpoint.

2.11 Methods of Recycle. The normal recycle of scrubbing solution to the feed involved the batch transfer (usually about 360 gallons every 18 hours) through a throttling valve to each feed batch. Part way through the campaign, in-line leakage through the valve seat was observed following a routine recycle of scrubbing solution. The rate of leakage was less than the theoretical average of 20 gallons per hour. With subsequent batch recycle, the leakage became worse, and further manipulation of the valve was suspended. Thereafter, the volume of solution (normal recycle volume minus the leak volume) required to maintain pseudo-equilibrium conditions in the scrubbing system was jetted from the scrubbing solution tank through the ICPP evaporator, then back to the tank farm. This alternate method of recycle allowed continued operation of the WCF for an extended period. A slight increase in overall throughput was achieved because the recycle solution was concentrated in the evaporator. Thts alternate, though satisfactory for aluminum waste, could not be used beneficially for operation with zirconium waste. Operation of the evaporator with fluoride-bearing waste was avoided to prevent excessive corrosion of the evaporator tubes.

\subsection{Particulate Solids Removal}

Scrubbing of particulate solids from the WCF off-gas was accomplished both in the quench tower and the venturi scrubber. Further cleanup was accomplished by electrostatic forces and by filtration in the silica gel adsorbers and in the HEPA filters. The efficiencies of these system components are shown in Figure 5. The scrubbing system removed $99.9 \%$ of the entering particulate matter so that the average concentration of solids in the off-gas was reduced to about $2 \times 10^{-7} \mathrm{lb} / \mathrm{fl}^{3}$. The dusurber's remuved $90 \%$ of the entering sollds, and the final filters removed greater than $99.9 \%$ of the remainder. Thus, the average solids concentration in the off-gas leaving the WCF was less than $8 \times 10^{-12} \mathrm{lb} / \mathrm{ft}^{3}$. The release rate of $90_{\mathrm{Sr}}$ averaged near $0.1 \mathrm{millicurie} /$ day which is less than $0.1 \%$ of the established guide value.

The decontamination factors observed while calcining zirconium waste are shown in Table IV. In general, the factors are slightly better than those for operation with aluminum waste. The overall decontamination factor consistently exceeded $1 \times 10^{8}$ for the former waste; whereas, this factor with aluminum waste mostly ranged from $10^{7}$ to $10^{8}$.

\subsection{Removal of Ruthenium}

Removal of ruthenium from the WCF off-gas is accomplished in the scrubbing system and in the silica gel adsorbers. The efficiencies of these components for removal of ruthenium are also shown in Figure 5. The scrubbing system removed about $93 \%$ of the entering ruthenium, while the silica gel adsorbers removed between 96 and $99 \%$ of the remainder. Thus, the overall decontamination factors for ruthenium ranged from 103 to $10^{5}$.

For zirconium waste, again the decontamination factors, as shown in Table IV, were better than those for aluminum waste processing. The scrubbing 


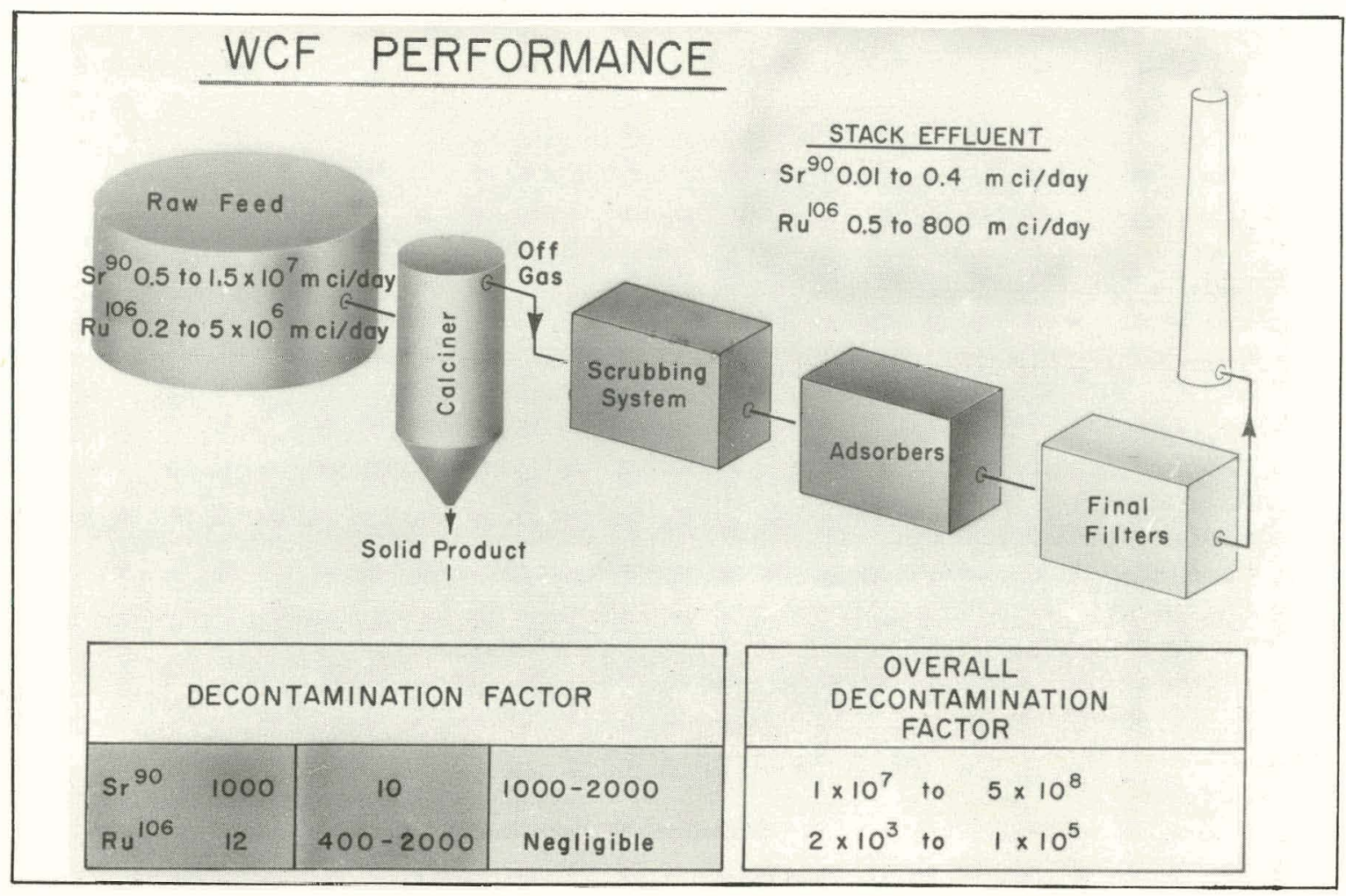

FIG. 5 PERFORMANCE OF THE OFF-GAS CLEANUP SYSTEM.

system removed about $99 \%$ of the entering ruthenium, while the adsorbers removed $99.9 \%$ of the remainder. Thus, the overall ruthenium decontamination factor for zirconium waste processing usually exceeded $10^{5}$. The daily release of ruthenium from this operation averaged about seven millicuries per day; this is less than $0.1 \%$ of the established guide value.

\section{TABLE IV}

PERFORMANCE OF WASTE CALCINING FACILITY WHILE CALCINING ZIRCONIUM WASTES

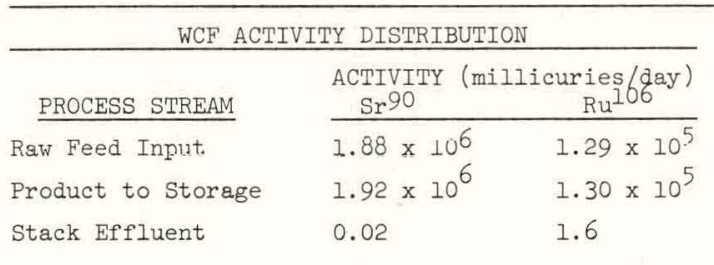

\begin{tabular}{lcc}
\multicolumn{3}{c}{ WCF DECONTAMINATION FACTORS } \\
\hline & $\begin{array}{c}\text { DECONTAMINATION } \\
\text { Fr90 } 90\end{array}$ & $\begin{array}{c}\text { FACTORS } \\
\mathrm{Ru}^{106}\end{array}$ \\
\cline { 2 - 3 } SYSTEM COMPONENT & 2750 & 100 \\
Serubbing System & 10 & 1000 \\
Adsorbers & 3000 & $\mathrm{nil}$ \\
Filters & & \\
Overall D. F. & & \\
Gross Feed Basis & $1.65 \times 10^{8}$ & $3.7 \times 10^{5}$
\end{tabular}

\subsection{Removal of Fluoride}

Samples of gas upstream of the silica gel adsorbers were collected and analyzed for total fluoride and fluorine contents. Results indicated that the concentration in the gas was less than the detection limit (about $1 \times 10^{-8} \mathrm{~g} / \mathrm{cc}$ ). Hence there was no environmental fluoride contamination problem during operation of the WCF with fluoride-type waste. 


\section{SPECIAL OPERATIONAL PERIODS}

Certain operating variations of process significance were attempted during the campaign to improve process performance or to attempt operation with previously undeveloped flow sheets. The results of these tests are discussed in the subsections which follow.

\subsection{Evaporation of Aluminum-Type Feed}

Prior to startup of WCF Run H-2, a system for concentrating aluminum feed in an evaporator was designed and installed in a tank previously used for adsorber regeneration, so that increased process throughout could be achieved[3]. Initially, feed control problems originating from insoluble silica gel in the tank were encountered (see Section 4.21). After cleanout of the system, the evaporator was operated over a 7-month period from May to November, 1967. With evaporation, the net rate of tank farm depletion averaged $80 \mathrm{gph}$; whereas, the net rate over a different 14-month period without evaporation averaged $67 \mathrm{gph}$. The gross feed rate to the calciner in both cases was essentially the same. Therefore, evaporation of the aluminum waste just prior to calcination in the WCF provided an increase of almost $20 \%$ in the net WCF throughput rate.

\subsection{Operation With Ammonium Nitrate Waste}

During the first WCF processing campaign[3], about 5,000 gallons of waste containing a high content of ammonium ion were calcined, but when insoluble mercury-hydroxamine-type solids were detected, operation was suspended pending evaluation of safety aspects of these solids in storage. Laboratory investigation prior to the second campaign indicated no potential atoragc problems, so it was decided to process this waste during this run. Approximately 265,000 gallons of this waste were converted to solids. Calcination problems were insignificant and proper control was achieved by adjusting the nozzle air-to-feed ratio. However, high pressure drops across the HEPA filters were experienced for a time during June and July, 1966 (see Section 6.22 on filter replacement). At that time, the temperature of the off-gas entering the filters was controlled at $85^{\circ} \mathrm{C}$. Upon reducing the off-gas temperature to $80^{\circ} \mathrm{C}$, the pressure drop across the filters immediately started to decrease, and thereafter the problem was greatly reduced. It is believed that the cause of the high pressure drop was due to incomplete decomposition of traces of ammonium nitrate and/or ammonia in the waste. Ammonium nitrate crystals undergo a physical change and greatly increase in size near $84^{\circ} \mathrm{C}$; thus, it is believed the larger crystals rapidly plugged the filters. Dropping the temperature produced a decrease in the crystal size, thereby greatly reducing the rate of pressure drop increase.

\subsection{Blending Various Wastes}

The ammonium nitrate problem with the filters led to a theory that proved that pressure drop increase could be controlled by diluting the concentrated ammonium ion in the scrubbing solution; therefore, batches of waste from a second tank without ammonium ion were processed alternately with the ammonia-containing waste. The great flexibility of the fluidized bed process in being capable of sustaining pseudo-equilibrium operation with widely varying 
feed compositions was adequately demonstrated. Very difficult-to-process wastes can be handled appropriately by alternating operation with more easily handled wastes.

This flexibility was also demonstrated when wastes from four separate tanks were blended. These wastes contained various chemical and radiochemical compositions. This operation indicated that wastes with high heat generation rates (due to radionuclide concentration) could be processed by blending with low-activity wastes, thereby producing a waste of intermediate activity and allowing use of a larger storage container without exceeding any given solids temperature limitation during storage. This demonstrated the feasibility of optimizing fuel processing schedules and interim liquid storage as well as the design of solids storage bins so that the most economical bin diameters could be used.

\section{SOLIDS STORAGE}

Calcined wastes were stored in stainless steel bins inside a buried concrete vault. The storage area, shown pictorially in Figure 6, contains seven 12-foot diameter bins, each having an overall height of 42 feet and a volume of 4400 cubic feet. Natural convective cooling air flowing up the bin surface removes the radio-decay heat from the solids.

Solids were conveyed pneumatically from the calciner to a cyclone above the bins. The solids separated from the air and fell by gravity into a distributor pipe below the cyclone, thence to the bins. Lines arranged around the distributor pipe at different elevations caused progressive filling of the bins. A special diverter valve at the bottom provided selective diversion to two of the bins.

Throughout the campaign, about 12,785 cubic feet of solids were sent to storage, 1670 from zirconium waste, 10,400 from aluminum nitrate waste, and 715 from nonradioactive feed used in startups. Three of the seven bins were essentially filled.

The maximum temperatures attained in the bins varied because the wastes originated from a wide variety of fuels with different burnup and aging times. The maximum center-line temperature reached was near $1085^{\circ} \mathrm{F}$, and the corresponding wall temperature was about $170^{\circ} \mathrm{F}$. Thus, for this solids storage design, there is no danger of exceeding the design limits $\left(1300\right.$ and $550^{\circ} \mathrm{F}$, respectively) of the solids and vessel walls for solids calcined from wastes stored at ICPP. 


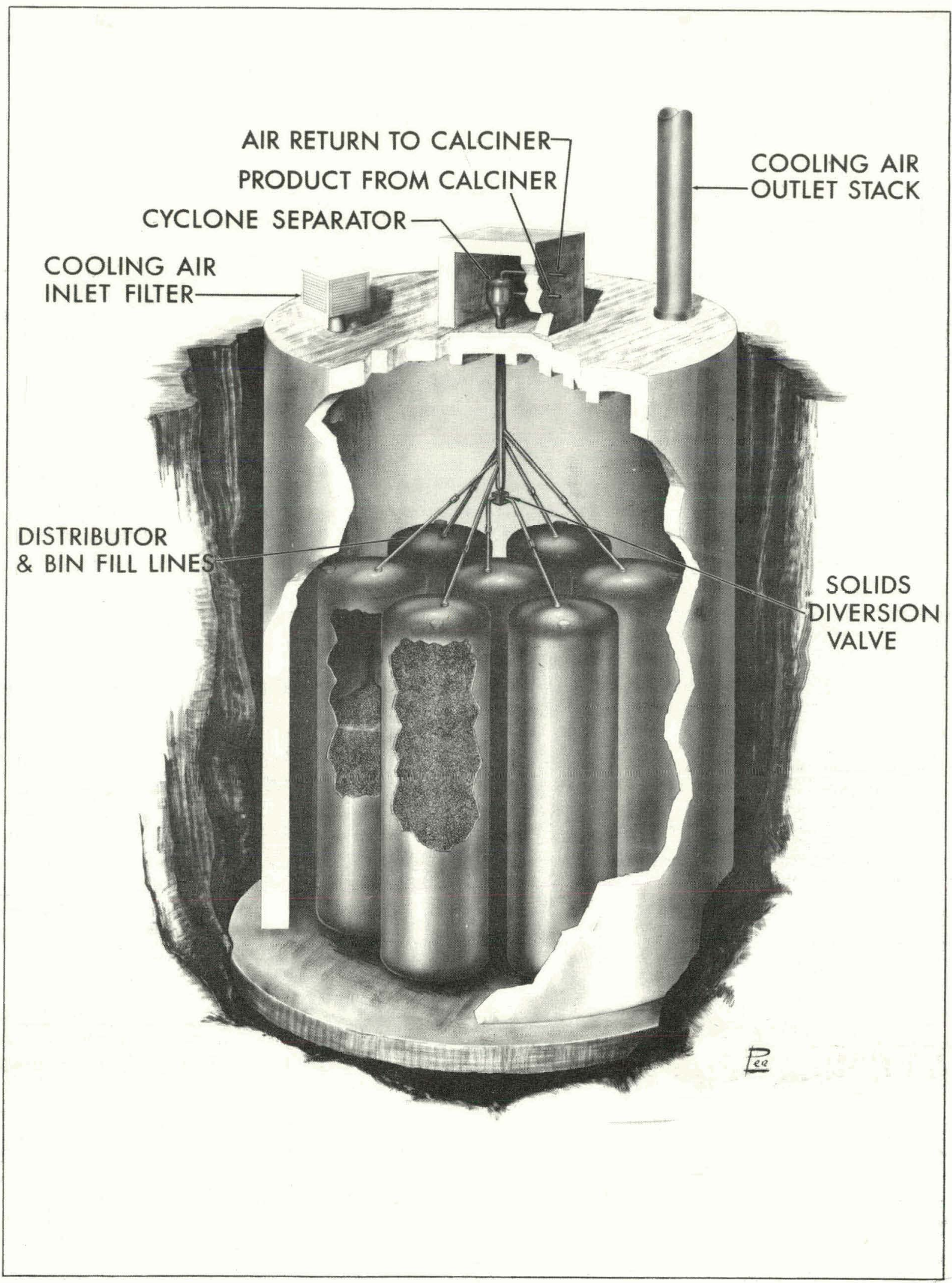

FIG. 6 WCF SOLIDS STORAGE BINS. 


\title{
IV. UTILITIES AND EQUIPMENT PERFORMANCE
}

\author{
1. UTILITIES
}

Air, steam, and water are supplied to the WCF by underground lines, each originating at the utilities service building, CPP 606. Electrical power is supplied by the CPP electrical distribution network, and emergency electrical power is supplied by a diesel generator at CPP 606. Fuel oil for the NaK furnace is suppled by two pumps from two storage tanks at the CPP 702 area. The fuel oil supply and return lines are underground. Service waste (condensate and cooling water) leaves the calciner in an underground line to join the main CPP service waste header.

\subsection{Air}

Air is supplied to the WCF at a nominal 100 psig. Part of this air is reduced by pressure reducing stations at the WCF to $50 \mathrm{psig}$ and $20 \mathrm{psig}$ to supply sparge air and instrument air. The air flow to the WCF averaged about 720 SCFM with peak rates as high as 850 SCFM. The air pressure averaged 100 psig with fluctuations as high as $105 \mathrm{psig}$ and as low as $95 \mathrm{psig}$. There was no WCF downtime due to air failure during this campaign.

\subsection{Steam}

High pressure steam is supplied to ICPP at a pressure of 135 psig from CPP 606. The pressure at the WCF is 127 to 130 psig. Steam consumption at the WCF is rather low and is used primarily in the heating and ventilating system and in the waste evaporator, WC-114. Lesser amounts are used to supply transfer jets. Consumption averaged $2,500 \mathrm{lb} / \mathrm{hr}$ for the entire campaign. During the three coldest months (January, February, and March) the usage was 2,650 $\mathrm{lb} / \mathrm{hr}$ against $1,690 \mathrm{lb} / \mathrm{hr}$ average for the three warmest months (July, August, and September). An ample supply of steam was available during the entire process run. No WCF downtime was caused by a steam failure.

\subsection{Water}

Water for the WCF is supplied by the fire water system and is not treated or softened. This results in hard water deposits building up in surfaces where heating and evaporation are taking place. Equipment items most affected were the spray coils in the heating and ventilating system and water-purged instrument tubing.

A water-purge line to a demister unit, WC-130, located in a thermally hot section of the calciner cell, plugged with hard water deposits in September 1967 and was abandoned for the remainder of the run. Most of the other problems associated with water-purges plugging were traced to aluminum fittings on water-purge lines. The plugging was caused by a reaction of the aluminum and the raw water to form water-insoluble salts. 
Water requirements for the WCF are low, generally 100 to $300 \mathrm{gph}$. The main process use is the waste evaporator condenser, WC-321, scrub system cooler, WC-307, and the heating and ventilation system. Minor amounts are used to cool the main off-gas blower bearings and to supply purge solutions to water-purged instruments and process equipment. There was no WCF downtime due to a water failure.

\subsection{Electrical}

Except for temporary loss of normal electrical power which is caused by furces external to the WCF, the electrical system proved to be reliable. These power failures and power dips were, in most instances, inconveniences which resulted in very little process downtime. In the two years of operation on this run less that 15 hours were charged against this system. The one exception to the power dips was an inconvenience that happened on June 7, 1966. At this time the normal electrical power voltage began fluctuating severely 6 to 8 times each minute. The emergency generator at CPP 606 started automatically, but since there was no complete loss of normal power, the existing load would not transfer to the emergency power circuit. At the WCF, the consequences appeared serious. The circuit breaker to the main off-gas blower (WC-251-B) tripped, and the spare blower could not be started. The equipment vent blower also stopped operating, and with no way to maintain vacuum on the system, all other equipment still operating had to be shut down. After 15 minutes the power oscillations ceased and regulated power returned. The WCF pruipment. was restarted and WCF operations were soon returned to normal. Although this was a freak occurrence, it identified a weakness in the existing emergency power system. Should a similar situation arise in the future, the main power dispatcher will cut off normal power to the CPP and allow the emergency system to assume the load until normal regulated power can be restored.

\subsection{Fuel Oil}

The NaK furnace is fired with No. 2 fuel oil which is pumped to the furnace room from two outside storage tanks at the CPP 702 area. The oil is circulated through a closed loop and supplied to the furnace controls at $30 \mathrm{psig}$. The fuel oil system operated very well during this run and required minimum maintenance. No process downtime resulted from a failure of this equipment. Oil was consumed at an average rate of $0.43 \mathrm{gpm}$ throughout this run, and a total of 378,684 gallons was used. Assuming a normal heating value for No. 2 fuel oil, the amount of heat released averaged about $3.7 \mathrm{million} \mathrm{Btu} / \mathrm{hr}$.

\subsection{Service Waste System}

The service waste drain system collects cooling water and steam condensate used at the WCF. The numerous auxiliary headers in this building are manifolded to a three-inch line which leaves the calciner building and is combined with other service waste streams at building CPP 709. Here the total service waste stream is monitored for activity.

Numerous pinhole leaks developed in the access corridor collection manifold during the processing campaign. Temporary repairs were made by patching the leaks, so no downtime resulted because of these failures. Preparations were made to repair and/or replace the entire system at the completion of the run. 


\section{NaK SYSTEM}

The heat required for decomposition of the calciner feed is supplied through an indirect heat transfer system. A eutectic metal $(\mathrm{NaK})$ is pumped through a three-inch stainless steel pipe to an oil-fired radiator and heater, past an expansion tank(s) which allows for expansion of the heated metal, to the heat exchanger in the calciner, and back to the electromagnetic pump. The system differs from conventional heat transfer systems in that the design of certain components is peculiar to liquid metal systems. These differences include the electromagnetic pump, flowmeters, and an oxide removal system. Additionally, the heat exchanger in the fluidized bed is constructed with specially designed "duplex tubes" which incorporate a helium-filled annulus around the tubes. The helium-filled annulus is used as a leak detection system.

The entire NaK loop and auxiliary components are of welded construction using either Type 316 or Type $316 \mathrm{~L}$, Schedule -40 stainless steel. The NaK system flow diagram is shown in Figure 7. Failures involving almost every component of this system caused $70 \%$ of the total plant downtime during this campaign.

\subsection{Leaks in NaK Piping}

NaK leaks in the piping outside of the calciner vessel occurred twice during this processing campaign. In both instances the leaks occurred in welds which had cracked due to temperature-associated stresses.

2.11 Expansion Tank, WC-103-A. On August 9, 1966, smoke was discovered in the NaK furnace room. An inspection showed smoke and fire at the base of WC-103-A expansion tank. The WCF operation was shut down in an orderly manner, the NaK was manually dumped from the NaK loop to the NaK dump tank, WC-104, and the Fire Department was notified.

The failure occurred in a weld joint on a tee connecting WC-103-A expansion tank to the NaK loop. Because of the difficulty in securing needed materials and in making repairs in the field, the expansion tank was isolated and the threeinch connecting tee was replaced with a straight pipe section.

Removal of one of the two expansion tanks did not seriously affect operation of the NaK loop. The single remaining tank was not large enough to take care of the volume change resulting from a temperature change of $700^{\circ} \mathrm{C}$; therefore, NaK had to be dumped from the NaK loop to the NaK charge tank during heating operations until the allowable NaK operating level was reached. Conversely, if the NaK were cooled below normal operating temperatures, additional NaK would have to be charged to the loop. The WCF system was not completely shut down during the repair period. The calciner bed was collapsed and allowed to settle on the distributor plate. Air purges were maintained below the distributor to prevent calcine material from sieving below the distributor caps. Total plant downtime charged to this incident was 94 hnurs.

2.12 NaK Dump Tank, WC-104-A-B. On March 31, 1967, the NaK fire detection system in the WCF north stairwell alarmed. At the same time a dense white smoke was observed in this area. The NaK was automatically dumped 


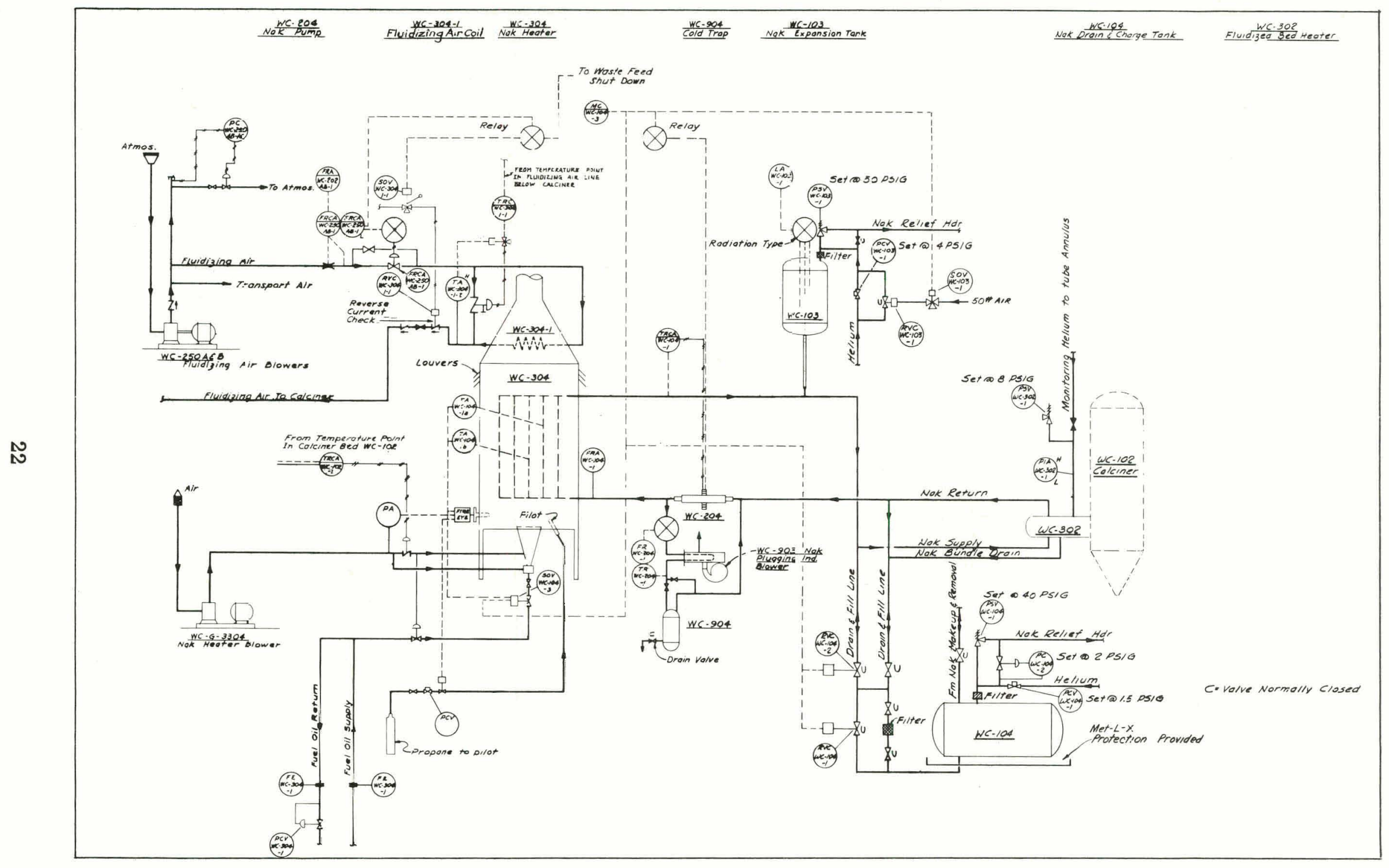

FIG. 7 NaK SYSTEM FLON DIAGRAM. 
from the NaK loop to NaK dump tank WC-104-A-B and a partial shutdown was enacted. Dense smoke initially hampered fire fighting efforts and the WCF was evacuated of all personnel except those actively fighting the fire. Within a short time, all the escaped $\mathrm{NaK}$ burned and the fire extinguished itself. Fire damage, per se, was negligible. The failure occurred in the weld at the small end of a $3 \times 1-1 / 2$ inch eccentric reducer on a NaK drain line entering WC-104-A-B dump tanks. This section was replaced with a new Type 316 stainless steel reducer. All welds in the vicinity of the failure were radiographed and dye checked and were found to be sound. Failure of this weld resulted in 143 hours downtime. A secondary equipment failure was caused by the smoke and Met-1-X powder being drawn into the air intake of the fluidizing air blowers. (Failure is described in Section IV-3.1.)

\subsection{Failure of Heat Exchanger WC-302}

On September 12,1966, NaK was discovered in the helium leak detection system for the heat exchanger tube bundle, WC-302. The leak was verified when $\mathrm{NaK}$ appeared in the helium vent line while this line was being vented to reduce pressures on the helium system. Refer to Figures 8 and 9 for a layout of the heat exchanger.

A complete shutdown of the WCF was initiated and the calciner bed was transferred to solids storage. Decontamination of the calciner cell equipment was started preparatory to repair of the tube bundle. During the intital decontamination stages, the calciner cell was found to contain 8 to 10 cubic feet of calcine material on the cell floor beneath the calciner vessel. The solids transport system failure leading to this situation is described in Secion IV-4.22. Decontamination of the cell was completed by October 1966.

It was estimated that repair of the tube bundle would take six to twelve months and replacement with a new tube bundle would take a longer period due to the procurement time required for such an item. The decision not to repair the NaK tube bundle, but to operate it with $\mathrm{NaK}$ in the helium annulus, was made after careful consideration of the consequences. The possibility of a NaK leak to the fluidized bed would be greater than before but the consequences of a leak would be identical. An analysis of the hazards resulting from such a leak are given in the ICPP WCF safety analysis report [1].

A review committee approved operation of the $\mathrm{NaK}$ heat exchanger, without repairs, subject to the following conditions.

(1) The NaK level in the NaK expansion tank would be instrumented so that NaK level at any point would be recorded and any reduction in $\mathrm{NaK}$ level would be indicated with an audible alarm.

(2) The NaK level in the NaK drain tank WC-104-A and -B would be determined each eight hours so an overall NaK inventory would be calculated.

(3) The NaK annulus and the helium annulus in the NaK tube bundle would be connected by an external line to assure equalizing pressure in the two areas. 


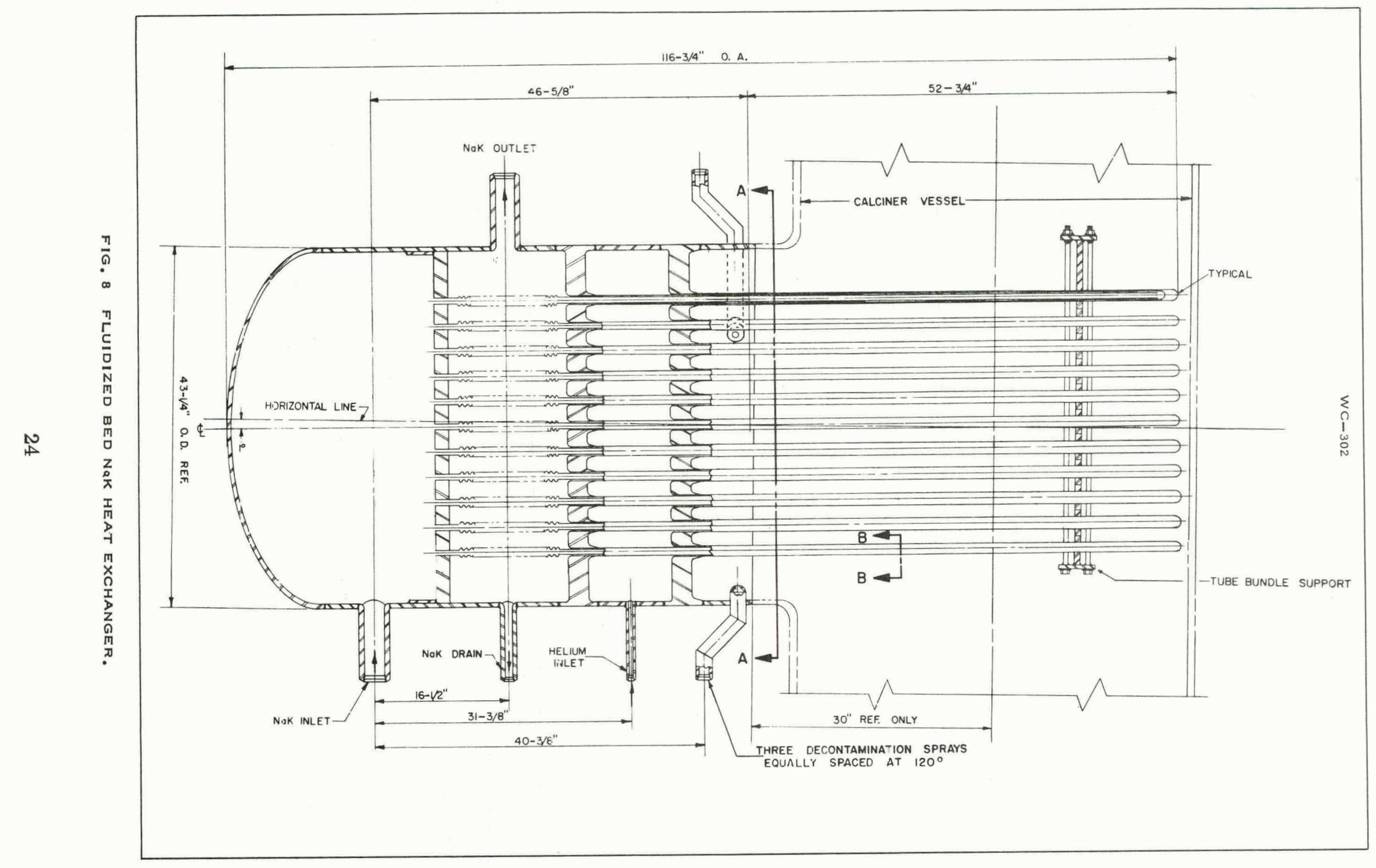




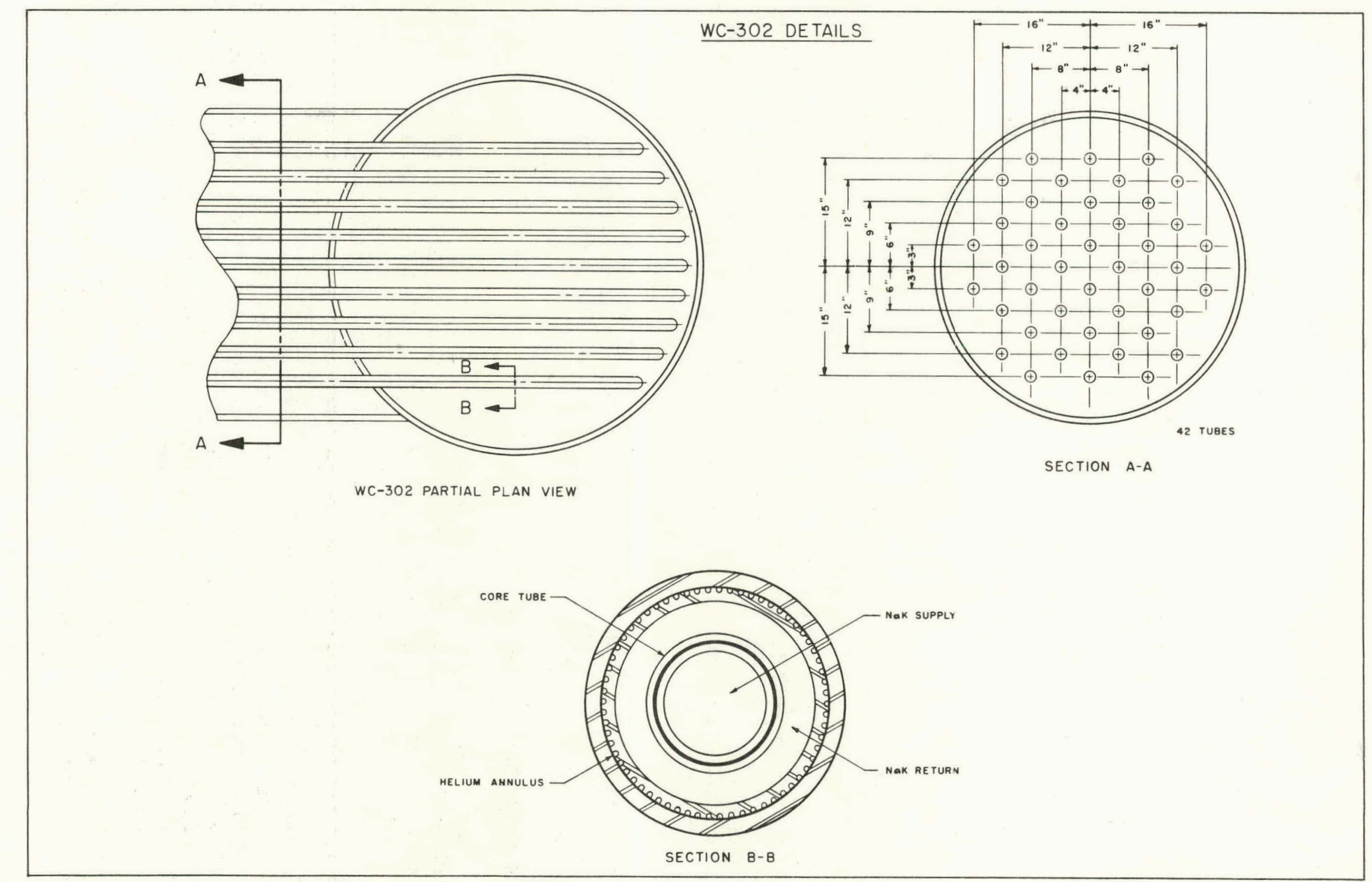

FIG. 9 NaK HEAT EXCHANGER DETAILS. 
(4) A smoke detection unit would be provided in the cell off-gas duct to determine external NaK leaks.

(5) The NaK oxide system would be operated routinely to assure a minimum sodium oxide concentration, hence, a minimum corrosion rate of the NaK loop.

(6) The NaK loop would be brought up to operating temperature slowly to reduce thermal shock to the system.

(7) Only aluminum nitrate wastes would be calcined without additional review.

Repairs were completed on November 8. "Cold" aluminum nitrate feed was processed until November 14 and processing of radioactive feed was resumed at that time. The total downtime assigned to the heat exchanger failure was 1,361 hours.

\subsection{NaK Pump, WC-204}

The NaK pump, WC-204, as shown in Figure 10, is an alternating-current electromagnetic conduction-type pump. It is completely sealed and has no moving parts. Operation is on the "motor principle", ie, a conductor sarrying a current in a magnetic field experiences a force which imparts motion to the conductor. In this case, the NaK stream itself is the conductor. The pump rate was controlled by adjusting an autotransformer in the power supply to the pump.

Six separate failures causing a total of 321 hours downtime were chargeable to the $\mathrm{NaK}$ pump and associated power system. These failures fall into three major categories: (a) leak in the flow tube, (b) internal shorting in the pump coils, and (c) internal shorting of the autotransformer. These failures are summarized in Table $\mathrm{V}$.

\subsection{Oxide Removal System}

An oxide removal system shown in Figure 7 is incorporated into the $\mathrm{NaK}$ system to reduce the sodium oxide content in the liquid metal and thus reduce corrosion of the stainless steel loop to acceptable levels. The presence of sodium oxide in the $\mathrm{NaK}$ can accelerate the corrosion of stainless steel although the attack of pure alkaline metals, other than lithium, on stainless steel is negligible.

The oxide removal system depends upon the decreased solubility of sodium oxide with decreased temperature. (The oxide concentration is calculated by determining the temperature at which the sodium oxide will precipitate from the NaK solution.) The system is designed to divert a small part of the total NaK flow (about $0.7 \%$ ) through a cold trap packed with stainless steel mesh. Here the $\mathrm{NaK}$ is cooled and sodium oxide is crystallized on the cooler stainless steel mesh and removed from the stream.

Although only 36 hours downtime could be directly charged to this system,

the operation of this system did present one problem which required hundreds of man-hours to solve. This problem was that the sodium oxide would not 


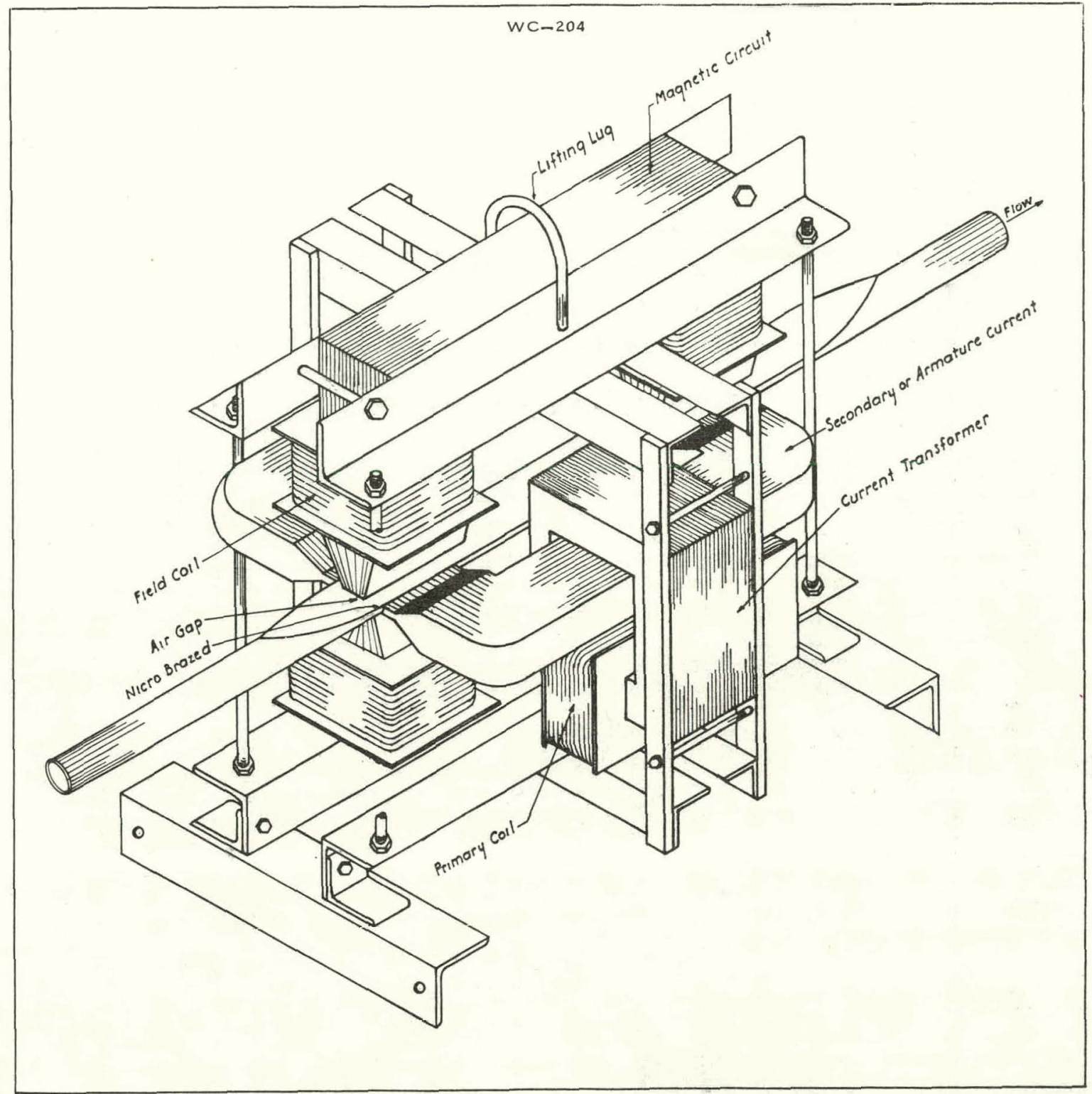

FIG. 10 NaK ELECTROMAGNETIC PUMP.

necessarily freeze out in the cold trap section but would plug in the first cool section encountered in the system, whether it was the flowmeter, economizer, plugging indicator valve, air cooler loop, or the inlet line to the system. The 36-hour downtime was used to install valves on the inlet and outlet lines to this system. Operation was somewhat improved by insulating and heattracing all lines and by reversing the flow through the economizer section. Plugging of this system continued to occur on an irregular basis but since it could be isolated by closing the two newly installed valves, plugs were removed without shutting down the NaK system and all other WCF operations. 


\section{Date}

September 12, 1966

October 29, 1966

May 17, 1967

July 14, 1967

August 27, 1967

October 12, 1967

January 30, 1968
Fuses continued to blow, shutting down pump operation. Leak in tube bundle WC-302 resulted in plant shutdown at this point.

Following WCF repair the NaK pump was again tested. Fuses blew at $50 \%$ of purp flow. Tests revealed no faulty components but pump performance was restored when four field coils were replaced.

A leak developed in the flattened part of the flow tube allowing NaK to leak from the loop causing a fire. NaK was drained from the loop, the pump was removed, repaired, and reinstalled.

The pump fuses continued to blow indicating an overload on the circuit. Trouble was traced to shorting of a primary coil with the metal parts of the pump structure. The areas effected were reinsulated.

Three 30-ampere fuses blew out on the autotransformer unit. Replacements were made and no further difficulties were encountered.

Three 30-ampere fuses blew out on the autotransformer unit. Replacements would not hold. Trouble was found in several

"stacks" in the autotransformer being shorted out. The autotransformer was replaced.

Repeat incicient of October 12, 196\%. The top stack of the autotransformer was replaced.

\section{Process Time Lost}

$13 \mathrm{hr}$

$144 \mathrm{hr}$

$122 \mathrm{hr}$

$13 \mathrm{hr}$

$0.5 \mathrm{hr}$

$22.5 \mathrm{hr}$

$6.0 \mathrm{hr}$

TOTAL $321.0 \mathrm{hr}$ 


\section{MECHANICAL EQUIPMENT}

During the period between WCF Hot Run No. 1 and No. 2, all mechanical equipment was inspected and overhauled when necessary to return it to its original design performance. As a result, no downtime can be assigned to mechanical equipment failures. Several units did fail during this period but the philosophy of providing alternate routings or spared equipment resulted in the plant's continued operation. Table VI is a summary of this equipment performance.

TABLE VI

WCF MECHANICAL EQUIPMENT

\begin{tabular}{|c|c|c|c|}
\hline $\begin{array}{c}\text { Type } \\
\text { Equipment }\end{array}$ & $\begin{array}{c}\text { Unit } \\
\text { Number } \\
\end{array}$ & $\begin{array}{c}\text { Hours } \\
\text { Operation }\end{array}$ & Comments \\
\hline 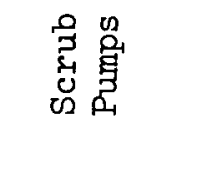 & $\begin{array}{l}\text { WC-208-A } \\
\text { WC-208-B }\end{array}$ & $\begin{array}{r}12026 \\
3972\end{array}$ & $\begin{array}{l}\text { Equal operating time for first } 380 \text { days. } \\
\text { Oil return failed on WC-208-B, April } 17 \text {, } \\
1967 \text {. This pump was down for the remain- } \\
\text { der of the run. }\end{array}$ \\
\hline 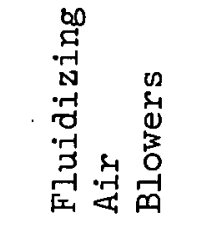 & $\begin{array}{l}\text { WC-250-A } \\
\text { WC-250-B }\end{array}$ & $\begin{array}{l}7295 \\
7295\end{array}$ & $\begin{array}{l}\text { The blowers were used alternately. A } \\
\text { bearing failure on WC-250-A on } 7 / 25 / 66 \\
\text { shut down this unit temporarily. }\end{array}$ \\
\hline 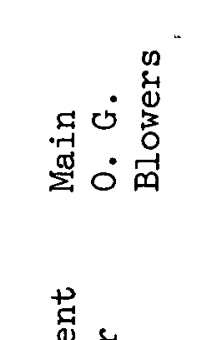 & $\begin{array}{l}\text { WC-251-A } \\
\text { WC-252-B }\end{array}$ & $\begin{array}{l}9605 \\
6393\end{array}$ & $\begin{array}{l}\text { WC-251-B operated continuously for first } \\
\text { year. Was then placed on standby due to } \\
\text { a water leak. On line } 10 / 12 / 67 \text { when } \\
\text { WC-251-A motor bearing failed. WC-251-A } \\
\text { back on line for remainder of the run } \\
\text { after the motor was rebuilt. }\end{array}$ \\
\hline 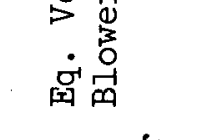 & WC-252 & 17278 & $\begin{array}{l}\text { This blower operated continuously except } \\
\text { for a 5-day period when motor bearings } \\
\text { failed. }\end{array}$ \\
\hline 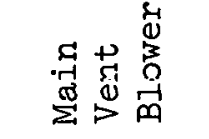 & WC-G-3301 & 17398 & Operated continuously for entire run. \\
\hline 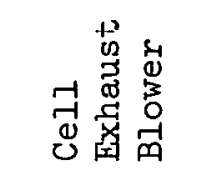 & WC-G-3302 & 17327 & $\begin{array}{l}\text { Operated continuously for entire run } \\
\text { except for 3-day period, october } 7-10 \text {, } \\
\text { 1966; bearings failed and were replaced. }\end{array}$ \\
\hline 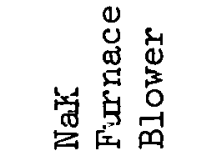 & WC-G-3304 & 14589 & $\begin{array}{l}\text { Operated continuously during processing } \\
\text { periods. }\end{array}$ \\
\hline
\end{tabular}




\subsection{Fluidizing Air Blowers}

There were no major mechanical problems experienced with either WC-250-A or WC-250-B fluidizing air blowers. These blowers provide the air necessary to (a) operate the solids transport system and (b) fluidize the calcine material in the calciner ressel, WC-102.

On July 25, 1966, blower WC-250-A was shut down for repairs due to a bearing failure. The process continued uninterrupted by using the spare blower, WC-250-B.

The only other downtime for these blowers happened on March 31, 1967, and May 17, 1967. Met-L-X, fire extinguisher compound, used for fighting $\mathrm{NaK}$ fires on these two dates was drawn into the fluidized air blowers' suction lines, plugging a screen on the blower inlets causing the blower motors to overload and shut down the line. Removal of the Met-L-X from the screen corrected the problem. No downtime was lost due to the blowers being down since the $\mathrm{NaK}$ leak causing the fire resulted in a plant shutdown.

\subsection{Equipment Vent Blower}

The equipment vent blower, WC-252, maintains the vacuum on the equipment vent system. This blower proved to be quite reliable during the run and no downtime was assigned because of its failure. On Octoher 25,1966 , following dis covery of the $\mathrm{NaK}$ leak in the calciner tube bundle and during decontamination of the WCF equipment, the motor bearings for this blower failed. A crossover line installed from the suction of this blower to the suction of the main off-gas blowers, provided for such an eventuality, was used to provide vacuum to the equipment vent system while repairs were made. The blowers performed satisfactorily for the remainder of the run.

\subsection{Main Off-Gas Blowers}

The main off-gas blowers, WC-251-A and WC-251-B, maintain a vacuum on the calciner vessel and calciner off-gas system. These blowers deliver off-gas to the ICPP stack where it is discharged to the atmosphere.

Alignment and lubrication problems experienced in previous calciner runs were not present during this processing campaign.

On March 30, 1967, WC-251-B blower was shut down and WC-251-A was placed on line when a routine check revealed fluid leaking from one of the water cooled bearing packings of WC-251-B off-gas blower. The fluid was acidic and was corroding the end plate of the blower. The cooling water to the bearing was shut off and the blower was maintained on standby for emergency use only. The only complete failure occurred on October 20, 1967. On this date the bearings on the electric motor powering WC-251-A failed. The standby blower, WC-251-B, was immediately placed in service without interruption to the calcining process. An investigation of the failure showed that the armature shaft was scored, the inboard and outboard bearings had completely failed, and the bearing housings were broken. The shaft was repaired and replacements were secured for all damaged parts. WC-251-A was placed back in service on November 1, 1967; WC-251-B was again placed on standby due to the 
water leak in the packing cooler. The off-gas blower performance remained satisfactory for the remainder of the run.

\subsection{Scrubbing System Pumps}

Sc rubbing solution pumps, WC-208-A and WC-208-B, circulate scrubbing solution from the quench tank, WC-108, to the quench tower, WC-107, and venturi scrubber, WC-907, and also recycle scrubbing solution to the waste hold tanks. These pumps are also used during decontamination of the off-gas cell for transferring decontaminants through the process lines. Scrub pump WC-208-B was operated during the "cold" WCF operation in March, 1966, and "hot" operations until April 8, 1966. At this time an attempt was made to switch operations to WC-208-A pump. The pump motor would not rotate but would trip the circuit breaker. The scrubbing solution at this time contained a large percentage of undissolved solids. These solids had settled in the pump bowl and jammed the impeller. Maintenance made a very quick entry into the off-gas cell, which at this time had radiation levels of 5 to $10 \mathrm{R} / \mathrm{hr}$, and turned the pump shaft with a pipe wrench. This freed the pump. WC-208-A and WC-208-B were then operated alternately on a 2 to 7 day cycle until April 17, 1967 . At that time a check of the oil inventory for the remote oil lubrication system indicated a failure of the oil line for scrub pump WC-208-B. It was not known whether the oil line to or from the pump bearings had failed. This pump was then placed on standby for the remainder of the campaign.

During the WCF shutdown on November-December, 1967, while the EM flowmeters in the feed system were being repaired (described in Section IV-5.2), the off-gas cell was partially decontaminated; the pump, WC-208-B, was removed from the off-gas cell for repairs. WCF operations were restarted with only WC-208-A pump in the quench system; however, it performed satisfactorily for the remainder of the run, and no shutdowns were encountered.

\subsection{Miscellaneous}

The main ventilation blower, WC-G-3301, performed continuously through the run. The cell off-gas blower, WC-G-3302, ran continuously except for a three day period, October $7-10,1966$, when repairs were necessary due to a fan bearing failure. A failure of either of these two blowers would not in itself cause a plant shutdown but the lack of ventilation in the WCF does affect the bearing temperatures of the main off-gas blowers and the temperature of the gas entering the final off-gas filters. The temperature change could with time produce conditions that would impede normal operations.

The NaK furnace blower, WC-G-3304, operated continuously at all times the NaK furnace was on line. No problems were encountered. A failure of this blower would shut down the $\mathrm{NaK}$ furnace resulting in an immediate shutdown of the WCF. 


\section{VALVES AND PIPING}

\subsection{Valve Failures}

Valve failures, per se, were not responsible for any lost processing time during this campaign. Failures when they did occur, with one exception, RVCWC-108-5, happened during operating periods with "cold" feed preparatory to processing radioactive waste, or while decontaminating equipment following a plant shutdown. Table VII summarizes these valve failures.

\subsection{Piping Failures}

Piping failures resulting from plugging of process lines with solids or eroding out of process lines by the calcine product were a continuing problem during this processing campaign. However, only on one occasion on March 7, 1967, did this necessitate a shutdown of the process.

4.21 Plugging of the Feed System. During the first four months of operation, severe plugging in the feed system continued to plague the process. During one week in July 1966, only one of the three feed nozzles remained operable. Between the dates May 12 and September 12, 1966, the " $B$ " feed nozzle was plugged completely and could not be used. The restrictions were believed to be caused by (a) solids being recycled to the feed system from the quench system and (b) solids resulting from concentrating the aluminum nitrate wastes from the permanent storage tanks in the newly installed waste evaporator, WC-114. Calciner operations did improve when recycle of the scrubbing solution to the feed system was discontinued. Further improvement was also noted when raw, unconcentrated feed was processed. Tests were conducted by recycling scrub solution and concentrating the aluminum nitrate wastes, but plugging in the feed system remained a major problem.

Following decontamination of the WCF for NaK tube bundle repairs in October - November, 1966, the calciner feed system was inspected. The electromagnetic flowmeter for the "B" feed line was found plugged with a mixture of sand and silica gel. The sand originated from the "cold" calcine materials used as an initial calciner startup bed. This calcine had been produced during cold testing when sand was used as a calciner startup bed. The silica gel originated from the newly installed waste evaporator. This vessel previously had been used as a wash receiver for the sllica gel adsorbers. Washing of the adsorbers had transferred silica gel to this tank where it remained until this vessel was used to concentrate the raw feed.

Steps taken to prevent reoccurrence of the plugging problems were: (a) the WC-114 evaporator was flushed until the silica gel residue was completely removed and (b) crushed "dolomite" was substituted for cold calcine as a startup bed in future WCF startup's (Dolomite was preferred because it is completely soluble in the scrubbing system, whereas sand in the cold calcine is ' not.)

Following resumption of WCF operations in December 1966, feed was concentrated in the evaporator and the scrubbing solution was recycled to the feed system. The feed system operated satisfactorily for the rest of the run without encountering major plugging. 


\begin{tabular}{|c|c|c|}
\hline Date & & \\
\hline $3-18-66$ & $\begin{array}{l}\text { RVC-WC-i.19-i (on WCF to CPP } 604 \\
\text { Waste Evapcrator transfer iine) }\end{array}$ & $\begin{array}{l}\text { The seal bellows ruptured during prestartup operations. } \\
\text { The valve was removed and replaced with a pipe section. }\end{array}$ \\
\hline $4-15-66$ & $\begin{array}{l}\text { TRC-WC-354 \& TRC-NC-356 (steam } \\
\text { controller to WC-354 \& WC-356 }\end{array}$ & $\begin{array}{l}\text { The electronic control system to the two valves failed. } \\
\text { The controllers were converted to pneumatic control. }\end{array}$ \\
\hline $10-66$ & RVC-WC-105-1 (WC-105 drain valve) & $\begin{array}{l}\text { Valve seat contained welding slag. Removed and replaced } \\
\text { during October-November, } 1966 \text {, shutdown. }\end{array}$ \\
\hline $10-66$ & Steam service valves & $\begin{array}{l}\text { Valves which had developed steam leaks in connection and } \\
\text { packing were repaired during October-November, 1966, shut- } \\
\text { down. }\end{array}$ \\
\hline $10-66$ & $\begin{array}{l}\text { RVC-WC-107-2 (Quench flow con- } \\
\text { trol valive) }\end{array}$ & $\begin{array}{l}\text { A small bellows leak discovered during October-November; } \\
1966 \text {, shutdown. Spare line and valve put in service. } \\
\text { RVC-WC-107-2 to be used only if spare failed. }\end{array}$ \\
\hline $10-66$ & $\begin{array}{l}\text { RVC-WC-102-10 (On south product. } \\
\text { takeoff line) }\end{array}$ & $\begin{array}{l}\text { The valve stem plugged with calcine during decontemination. } \\
\text { RVC-WC-102-9 and -10 were removed during the } 10-66 \text { plant shut } \\
\text { down. }\end{array}$ \\
\hline $5-30-67$ & $\begin{array}{l}\text { RVC-WC-108-5 (Quench recycle } \\
\text { valve) }\end{array}$ & $\begin{array}{l}\text { This valve controls solution transfers from the quench sys- } \\
\text { tem to the feed system. The valve failed to close allowing } \\
\text { continuous recycle to feed system. The leak rate was less } \\
\text { than normal recycle. The valve was not repaired at this } \\
\text { time. }\end{array}$ \\
\hline $11-13-67$ & $\begin{array}{l}\text { Check Valve (WC-114 solution } \\
\text { inlet) }\end{array}$ & $\begin{array}{l}\text { The packing on the valve flange failed. Solution ran to the } \\
\text { cell floor. Packing was replaced during "hot" operations. }\end{array}$ \\
\hline $11-27-67$ & RVC-WC-105-5 & Repaired during the November 1967 plant shutdown. \\
\hline $11-67$ & Steam Service Valves & Repacked and repaired leaking valves. \\
\hline $1-17-68$ & RVC-WC-105-5 & $\begin{array}{l}\text { Valve failed to close. Bntered the cell during "hot" oper- } \\
\text { ations and attached air line to operator to ald in closing } \\
\text { this valve. }\end{array}$ \\
\hline
\end{tabular}


4.22 Erosion in the Product Transport Lines. The solids produced in the calcining process are conveyed pneumatically from the calciner vessel through a buried, concrete encased, three-Inch line connecting the calciner cell to the solids storage vault. Air is supplied to this line by fluidizing air blower WC250-A or -B. Solids from the calciner vessel are discharged into the transport line from the cyclone fines jet and from two product takeoff lines from the calciner vessel. Occasionally solids may be discharged to this line from the calciner drain line. The solids transport system is shown in Figure 11.

The pneumatic transport of the calciner solids is normally performed at low velocities, and impingement of calcine particles on the metal pipe and elbows therefore results in little or no erosion of the transport system. However, conditions are present in which calcine material, if carried at high velocities, can erode a hole in the stainless steel lines. On two instances this occurred during this processing campaign.

On October 6, 1966, during decontamination of the WCF to prepare for repair of the NaK tube bundle, an estimated 8 to 10 cubic feet of calcine material was discovered on the calciner cell floor beneath the south product takeoff line as shown in Figure 12. (The relatively simple decontamination procedure used to remove this solid material without any problem is given in Section V-1.2.) A hole eroded in a short-radius bend on the south product takeoff line approximately three feet above the three-inch product takeoff line. Because of this, all bends and junctions in the product transport system were either X-rayed or tested for thickness with an ultrasonic detector. Several areas at bends or junctions in the three-inch pipe were discovered to be thinning. These spots were reinforced by welding a piece of Schedule-80 pipe to the thinned spot. The south product line was replaced.

On March 7, 1967, calcine product was again discovered on the calciner cell floor in the course of daily cell inspections initiated after the first calcine leak. (Decontamination preparatory to the repair of this item is described in Section V-1.2.)

This calcine leak again originated on the south product takeoff line but at a point near the junction of this line with the calciner vessel opposite the entry of a dilution-air line. The dilution alr is used to control the product flow from the calcine vessel. The hole in the dilution-air line was off-centered and had caused severe local erosion of the inlet to the product takeoff line. The corresponding section of the north product takeoff line had suffered no erosion. The entire transport system was again radiographed and tested for thickness. Several spots which had thinnned since the previous inspection were reinforced. Both product takeoff lines were replaced with 17-4 PH stainless steel and heat treated following fabrication to produce maximum hardness. No further leaks developed in the product transfer system for the remainder of the run.

4.23 "Cold" Startup Bed Addition Line. During the cold startup period following the plant shutdown on March 8, 1967, to repair the eroded solids transport line, a final inspection of the calciner cell revealed material identified as startup bed (dolomite) on the cell floor. Further inspection showed a hole in a 45-degree bend of the cold bed addition line. Erosion from numerous calciner fillings during "cold" testing. and later "hot" operations caused this failure. Since the line was not in contact with radioactive material and is not 


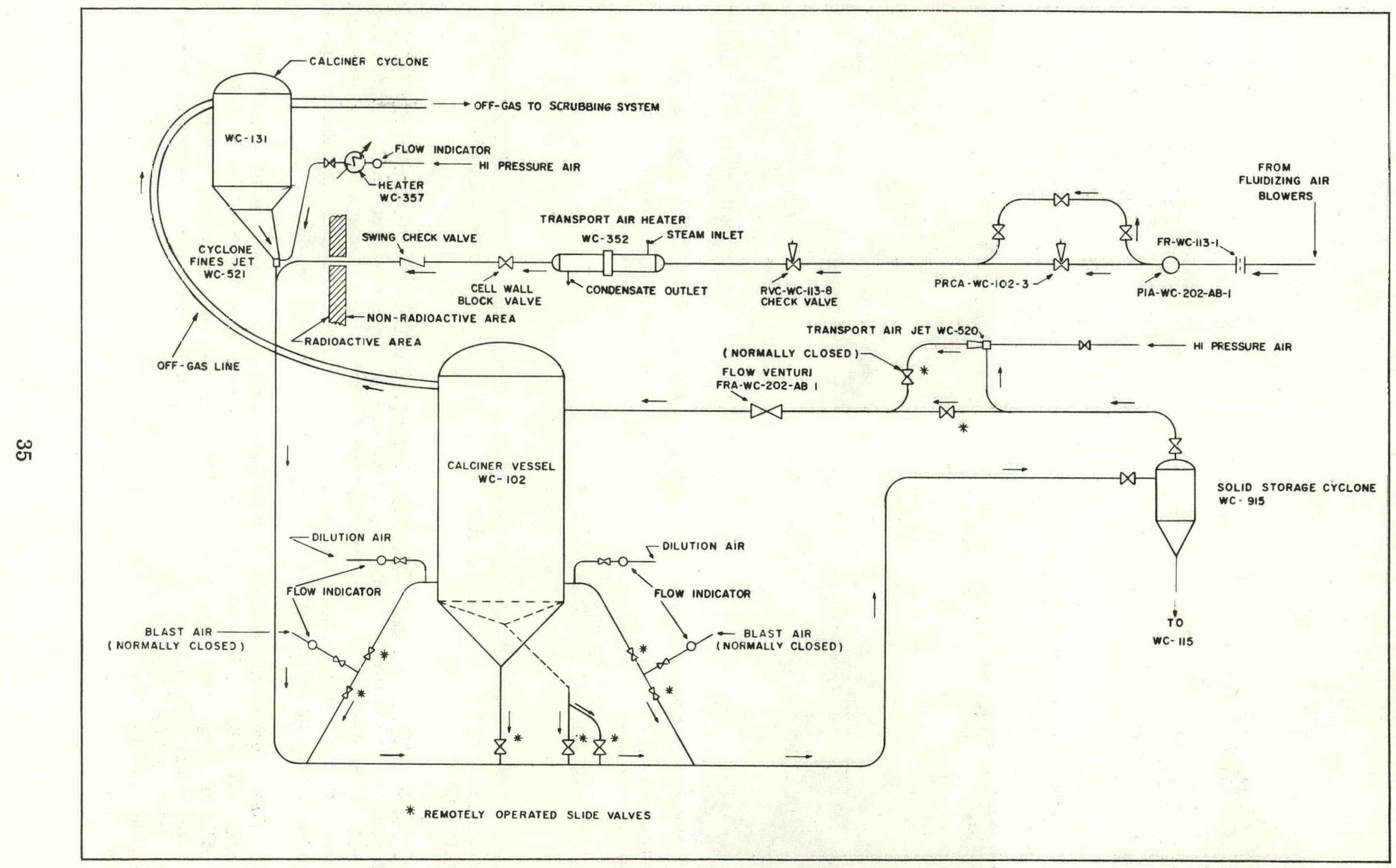

FIG. 11 TRANSPORT AIR SYSTEM. 


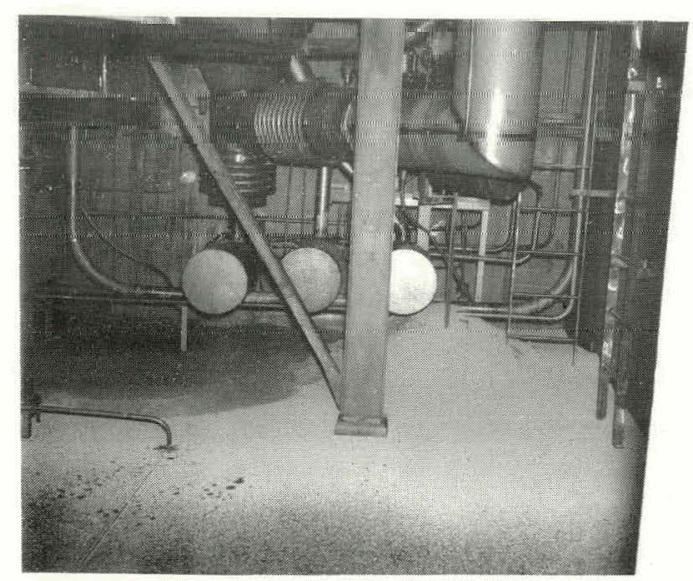

PHOTOGRAPH

OCTOBER 6, 1966

ESTIMATED 8 TO 10 CUBIC FEET OF SOLIDS ON CALCINER CELL FLOOR BENEATH CALCINER VESSEL BEFORE CLEANUP.

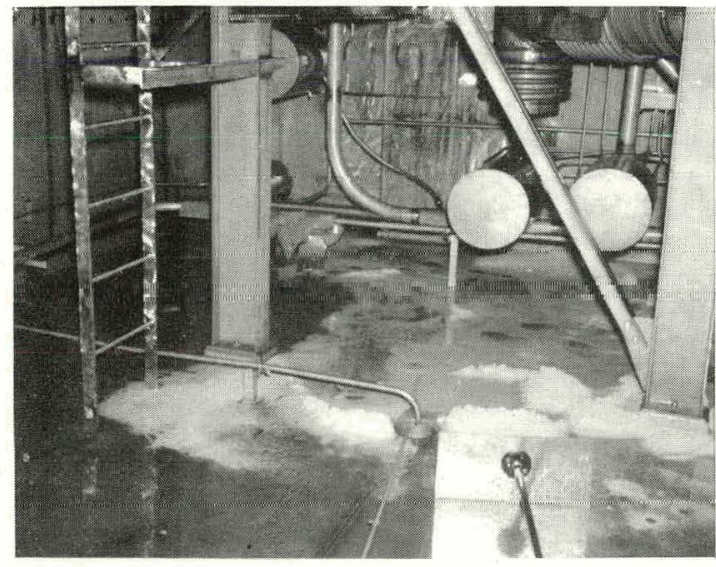

PHOTOGRAPH 3

INITIAL CLEANUP PHASE OF CALCINED SOLIDS SHOWN IN PHOTO 1 SOLIDS WERE SIMPLY SLURRIED AND FLUSHED COLLECTION TANKS WITHOUT PROBLEM. FIG. 12 CALCINER CELL AFTER PRODUCT TAKEOFF LFAK.

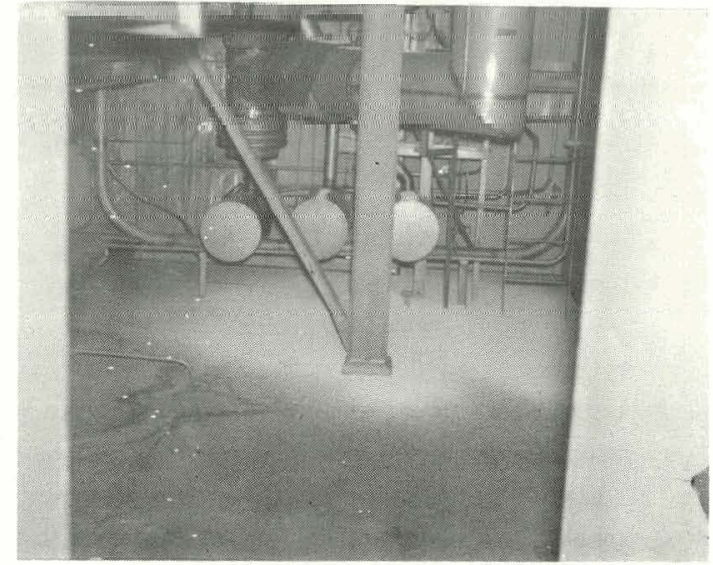

PHOTOGRAPH 2 MARCH 7, 1967

SECOND LEAK IN TRANSPORT AIR LINE. AGAIN SIGNIFICANT QUANTITY OF SOLIDS

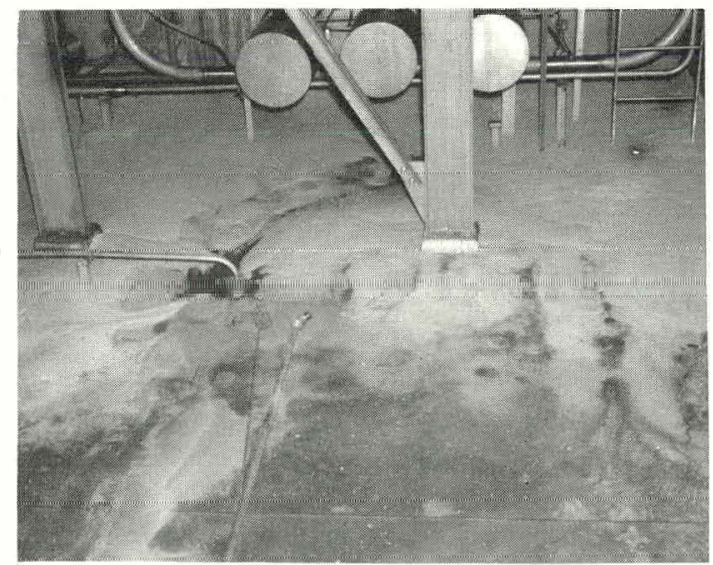

PHOTOGRAPH 4

FINAL CLEANUP PHASE OF THE SOLIDS SHOWN IN PHOTOGRAPH 1.

used except during WCF startup, a temporary patch was installed over the hole. The "cold" bed addition line was scheduled to be redesigned and replaced following this campaign.

4.24 Solids Storage Distributor Pipe. Shortly after beginning processing of zirconium fluoride type waste, it became apparent from the temperature profiles of the solid storage bins that the calcine material was not entering either of the two bins reserved for this waste. Instead the temperatures showed solids were continuing to fill bin 5 containing alumina solids.

The eight-inch vertical distributor pipe for the second solids storage vault, WC-136, shown in Figure 13, is constructed so that bins 4, 3, 5, 7, and 6 fill in sequence from overflow lines located at increasing elevations. Bins 1 and 2 are filled from the bottom of the distributor line by activating a solid diverter valve. The valve is a horizontal pipe section extending from the bottom of the distributor pipe. The angle of repose of the solids in this line prevents the solids in the vertical distributor pipe from falling into bins 1 
and 2. The valve is activated by introducing air to the horizontal section disturbing the angle of repose of the calcine material, moving this material selectively to either bins 1 or 2 .

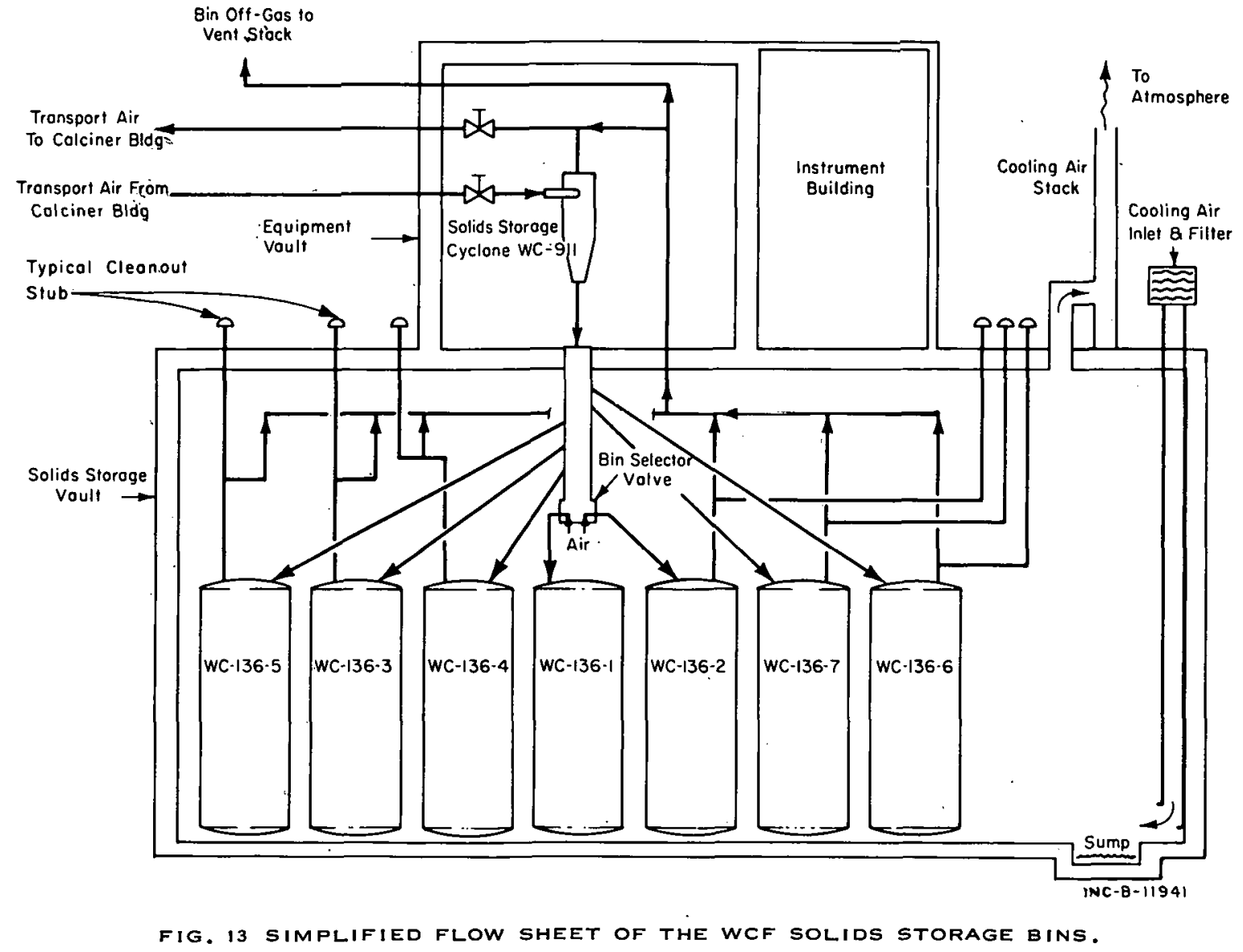

Since bins 1 and 2 were not receiving calcine solids and storage bin 5 continued to fill, it was concluded that the calcine had been packed in the distributor solidly enough to prevent flow downward. This was confirmed when an attempt was made to clear the distributor. A solid plug was encountered about two feet above the base of the distributor pipe. Since the WCF was in operation and the transport of the calcine material was dependent on maintaining a vacuum on the solid storage bins, no further attempt was made to remove the plug at that time. The plug was rodded out after the run.

4.25 Fouling of tubes in WC-305 Off-Gas Heater. Saturated off-gas from the secondary de-entrainment cyclone, WC-910, is superheated in the off-gas heater, WC-305, before entering the silica gel adsorbers. The purpose of this heater is to add sufficient heat to the saturated off-gas stream to prevent condensation of water in the adsorbers and the downstream piping.

On July 28,1967 , it was noted that the pressure drop across WC-305 increased from a normal one-inch mercury differential to near a three-inch mercury differential, and difficulty was being experienced maintaining the calciner vessel at the desired vacuum. It was concluded that the tubes in the heat exchanger', WC-305, were scaling over with aluminum salts which were entrained in thc off-gas stream and depnsited in the heated tubes. Steam to WC-305 
was turned off and the temperature of the tubes was allowed to drop below that of the off-gas stream. Within a 24-hour period, condensing moisture from the off-gas had cleared the fouled tube. Steam was again turned on to WC-305 to superheat the off-gas to the adsorbers. Plugging continued to occur at this point at infrequent intervals for the rest of the run. In each case, clearing was accomplished. by turning off the steam supply to WC-305 for 18 to 48 hours.

4.26 Miscellaneous. On Januray 21 and 22, 1967, surface water from rain and melting snow caused flooding in certain areas near the WCF. As a result of this flooding, ground water began leaking into both the waste hold cell and the hot sump cell. The sources of these leaks were identified as two yard valves whose extension handles were located in areas of deep water. The water followed the extension handle risers to the tile-enclosure surrounding lines, entering the WCF and on into the cells. A dike was constructed and the low area around the two yard valves was filled with dirt. This prevented further flooding of the WCF. More than 5,000 gallons of water was transferred from the two cells to the hot sumptank, WC-119, and on to the PEW evaporator system for processing.

\section{INSTRUMENTATION}

The overall WCF performance was good for most of this run in spite of problems encountered with the feed system (Section 4.21) during the first six months. This was possible because good instrumentation control of process conditions generally provided rapid recovery from severe process upsets. Most of the instrument problems encountered were minor and were easily corrected by the shift instrument man.

\subsection{Tomperature Measurement and Control}

Very few problems in this category were encountered during this processing campaign. These included the following:

(1) The off-gas humidity and superheat controllers, 'TRC-WC-908 and TRC-WC-305, had been interconnected so that TRC-WC-305 would automatically maintain $\mathrm{a}+10^{\circ} \mathrm{C}$ higher temperature than TRC-WC-908. This temperature differential would not stay constant without routine instrument adjustments.

(2) External decontamination of cell equipment usually resulted in destruction of several thermocouple leads. It was necessary to check all thermocouples after each decontamination sequence and replace those found to be faulty.

\subsection{Feed Rate Measurement and Control}

Control of the feed flow to the calciner vessel proved to be one of the major problems encountered during the first six months of operation. The inability to precisely measure and control the feed flow during this period was due to the following: 
(1) The flow-control valve and/or valve operator mechanism would stick.

(2) Solids would accumulate in the narrow throat of the electromagnetic flowmeter and restrict or completely shut off the flow of the feed.

(3) The bellows seal on the pneumatically operated feed nozzle cleanout plunger was subject to failure.

Cleanout of the entire feed, system including removal and cleaning of the electromagnetic flowmeter during the November 1966 plant shutdown resulted in an almost complete elimination of these problems as sources of process difficulties.

The original electromagnetlc flowmeters installed at the beginning of this run developed leaks on November 25, 1967. This was two weeks after processing of zirconium fluoride feed had been started. Fluorides in the blended feed almost completely destroyed the ceramic liners in the electromagnetic flowmeter after less than 350 hours contact time. The WCF was shut down and new flowmeters with "Kynar" liners were installed. This plastic proved to be adequate protection from the fluoride feed and no further flowmeter problems were encountered.

\subsection{Measurements of Liquid Levels, Density, and Pressure}

Most instruments in this category functioned well and required only occasional maintenance. The variables are measured by differential pressure transmitters and are converted to readings on recorders, indicators, or recorder controllers. The most frequent causes of error in these measurements are restrictions or plugs in one or both of the pneumatic purge lines rather than faulty instrument components.

Plugging occurred most frequently in lines connected to the scrubbing system and adsorber liquid level lines. The purges in these two systems came in contact with salt solutions near the saturation point. The air bubbles used - as instrument purges caused crystallization of salts at the end of probes causing the plugging in the line.

The plugs were easily removed, when identified, by increasing the atr or water purge rates or, if completely plugged, by pressuring the line with a low volume, high pressure pump.

\subsection{Miscellaneous Instrument Problems}

Other instrument problems include: Power dips and fallures which cause the NaK furnace to shut down. This has been minimized by installing a 10-second delay which eliminates shutdown of this equipment if a short aingle power dip occurs.: 


\section{FILTERS}

\subsection{Equipment Vent Filters}

The equipment vent filter was changed eight times during the run. On-stream time ranged from a low of 34 days to a high of 168 days with an average life of 90.6 days.

The filter was changed because of either (a) high direct radiation reading at the fliter case or (b) high pressure drop across the filter element. The elght filter changes made during this run were necessary because of high radiation levels. WC-130, equipment off-gas demister, had been modified prior to this campaign and an increased filter life was obtained. In spite of a plugged water purge line to the mesh section of WC-130 demister during the last quarter of the run, the filter life was more than double that of the first processing campalgn.

\subsection{Main Off-Gas Filters}

Final filtration of the main calciner off-gas stream was accomplished by three parallel-connected filter units. Each unit consists of a removable housing which holds a roughing pre-filter and an AEC-type high-efficiency final filter. Each filter unit was in continuous service during the run except for brief periods when the filters were heing changed.

6.21 Filter Replacement Schedule. During this run only the pressure drop across the filters influenced the filter change schedule. A fllter was changed each time the pressure drop across the three filters reached ten inches of water. In order to determine which of the three filters was causing the most resistance to the off-gas flow, pressure taps were installed across each filter case. Each fllter was changed as needed. The filter change-out sohodule is shown in Table VIII.

6.22 Factors Influencing Filter Changes. Plugging of the filters has been identified as originating from two sources. The first was condensation of gases from the off-gas stream on the filter elements. The dampness plus the entrained solid material formed a glaze, sealing the filter. The second was due to a high rate of solids carry-over from the-silica gel adsorbers. Additional superheat applied to the WC-354 off-gas heater which is located upstream of the final filters reduced the condensation problem. The use of all four silica gel adsorbers rather than three reduced the velocity of the off-gas sufficiently through the adsorbers so that fine solids were not carried on to the filter. One filter change was also necessary after the element had been on stream for 23 days. The overall pressure drop across this filter suddenly decreased from 7.4 to 5.5 inches $\mathrm{H}_{2} \mathrm{O}$. At the same time a sharp increase in the particulate activity of the off-gas to the stack was detected. This off-gas filter was changed and the activity level returned to normal on the off-gas stream. Inspection of the filter during disassembly at the TAN area showed the following:

(1) The filter frame had been constructed of carbon steel with aluminum used as spacers.

(2) The calciner off-gas had almost completely destroyed both metals allowing the filter media to collapse. 
TABLE VIII

WCF FINAL FILTER REPLACEMENT DATA

\begin{tabular}{|c|c|c|c|c|c|}
\hline 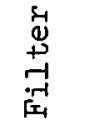 & $\begin{array}{l}\text { East } \\
\text { Filter }\end{array}$ & $\begin{array}{l}\text { Middle } \\
\text { Filter }\end{array}$ & $\begin{array}{c}\text { West } \\
\text { Filter }\end{array}$ & $\begin{array}{c}\text { Days } \\
\text { Service }\end{array}$ & Comments \\
\hline 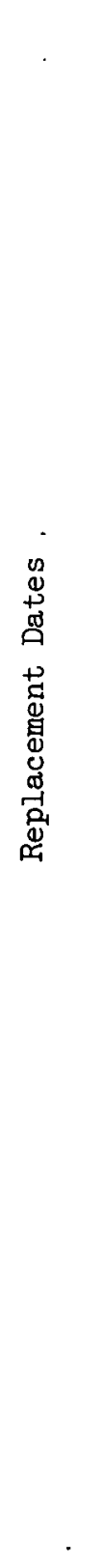 & $\begin{array}{l}3-14-66 \\
6-17-66 \\
7-6-66 \\
8-2-66 \\
12-1-66 \\
3-27-67 \\
311-22-67 \\
3-13-67\end{array}$ & $\begin{array}{l}3-14-66 \\
6-20-66 \\
7-11-66 \\
8-29-66 \\
8-17-67 \\
1.0-31-67 \\
\vdots\end{array}$ & $\begin{array}{l}3-14-66 \\
6-21-66 \\
7-11-66 \\
12-23-66 \\
5-22-67 \\
6-14-67 \\
10-27-67 \\
2-9-68 \\
\\
7\end{array}$ & $\begin{array}{r}- \\
95 \\
98 \\
99 \\
19 \\
21 \\
20 \\
27 \\
49 \\
132 \\
165 \\
116 \\
150 \\
23 \\
353 \\
170 \\
134 \\
75 \\
70 \\
108 \\
113 \\
7\end{array}$ & $\begin{array}{l}\text { Initial Replace- } \\
\text { ment } \\
\text { Filter Elements } \\
\text { Collapeed }\end{array}$ \\
\hline & 10 Filters & 6 Filters & 8 Filters & . & . \\
\hline $\begin{array}{l}0 \\
4 \\
4 \\
4\end{array}$ & 72.5 Days & 120.8 Days & 90.6 Days & $\begin{array}{l}30.2 \\
\text { Days }\end{array}$ & \\
\hline
\end{tabular}




\section{SHUTDOWN, DECONTAMINATION, AND INSPECTION}

\section{SHUTDOWN AND DECONTAMINATION}

After shutdown due to equipment fallure or as a scheduled event (at the completion of a processing campaign) a partial or complete decontamination of operating cells and equipment was performed. The decontamination sequence in each instance was tailored to accomplish the degree of cleanup required for the specific repair work to be accomplished. The main criterion used in any decontamination sequence is to reduce the radiation level in the working areas to an acceptable level using a minimum volume of decontaminating solutions. The last part of that criterion is very important after zirconium fluoride waste has been processed. These decontaminating solutions remove large quantities of fluoride which subsequently must be sent directly to permanent storage without benefit of volume reduction in the CPP 604 PEW waste evaporator system. This is necessary because the corrosion rate of stainless steel is very rapid when contacted with fluoride solutions at boiling conditions.

\subsection{WCF Shutdown}

The WCF was shut down on four instances during this processing campaign. 'These shutdowns were considered complete in that the calciner bed was transferred to solid storage and a major decontamination sequence was started in one or more cells. Details of the shutdowns are given in Sections 1.11 through 1.14 and decontamination techniques follow in Sections 1.2 through 1.24.

1.11 NaK Leak to Helium Leak Detection System. On September 12, 1966 , $\mathrm{NaK}$ was discovered in the helium leak detection system. Because of the nature and implication of this leak, an immediate plant shutdown was started. Feed processing was discontinued, the $\mathrm{NaK}$ system was shut down and drained, and the calciner bed was transferred to solids storage.

Inttially only the calciner cell containing the NaK Heat Exchanger, WC-302, was to be decontaminated, but cursory inspection of the calciner and the off-gas cells revealed additional problems. A pile of calcine material estimated at 8 to 10 cubic feet (see Figure 12, plate 1) was found beneath the calciner vessel in the calciner cell, and stalactite- and stalagmite-type deposits composed of dried salts from the quench system were found in the off-gas cell. The external contamination of these two cell complicated the normal decontamination sequence; but in spite of the additional problems, decontamination of the calciner cell was completed on October 6,1966, and decontamination of the off-gas cell was completed on October 16,1966 .

1.12 Eroded Sollds Transfer Line. On March 7, 1967, during a routine daily inspection of the calciner cell, calcine solids were discovered on the floor and piping beneath the calciner vessel (see Figure 12, plate 1). A mirror and lightling arrangement had been installed during the previous shutdown so leaks of this nature could be immediately detected. A plant shutdown was begun on March 8, 1967, and completed 38 hours later. 
Only the calciner cell was decontaminated during this shutdown. This was completed on March 17 and turned over to maintenance for repairs.

1.13 Electromagnetic Flowmeter Fallure. On November 25, 1967, the ceramic lined throats of the three electromagnetic flowmeters for the feed system failed, contaminating the flowmeter cubicle and sample gallery. The WCF was shut down and the flowmeter cubicle and the off-gas cell were decontaminated in preparation for repairs. The off-gas cell was cleaned up so a quench pump and flow control valve which had failed during the previous processing sequence could be repaired. Decontamination of the flowmeter cubicle was completed within 24 hours and the off-gas cell in 7 days.

1.14 Shutdown at Completion of Hot Run 2. Shutdown and completion of the second radioactive processing campaign for the WCF was scheduled for March 24, 1968. In an attempt to reduce the concentration of fluoride in the calciner bed and the quench system, processing of zirconium fluoride waste was discontinued on March 7, 1968, and processing of aluminum nitrate waste was resumed. The WCF was shut down as scheduled and decontamination of the Waste Hold Cell, Off-Gas Blower Cell, Calciner Cell, and Off-Gas Cell started. Decontamination continued on a part time basis due to other plant processing commitments.: On June 17, 1968, the radiation levels were reduced to a low enough level so maintenance activities could begin. A total of 16,300 gallons of solution was returned to permanent.storage as a result of this decontamination sequence.

\subsection{WCF Decontamination}

Decontamination of the various systems at the WCF proved to be a relatively simple operation with few equipment items requiring special attention. The initial decontaminant used was 4 to $5 \mathrm{M}$ nitric acid maintained at 60 to $90^{\circ} \mathrm{C}$ while contacting the equipment. The acid would dissolve the residual calcine particles scattered through the equipment and piping and would usually reduce the radiation levels to less than 2 to $3 \mathrm{R} / \mathrm{hr}$. The nitric acid flush was then followed by alternate water and nitric acid flushes. The final decontamination phase used alternate rinses of 4502 Turco and Oxalic acid, or alternate rinses of caustic and tartaric acid-nitric acid. External contamination could generally be removed by spraying the area with water until all the solids were removed and then wiping or mopping clean with 4502 Turco followed by Oxalic acid.

The cell sprays provided in each proved to be ineffective for removing external contamination. A large volume of decontaminant could be sprayed to a cell but the sprays would not necessarily cover the contaminated area or provide enough contact time to remove the contaminant. A well directed spray in the hands of an operator was much more efficient.

This latter technique was used effectively in removing large quantities of solids from the floor of the calciner cell after leaks from the solids transfer lines (Section IV-4.22). High pressure water streams were directed at the piles of solid in order to produce a slurry which was then washed with low velocity dilution water through the floor drains to the waste collection tank. Periodically, a hoe-type scraper with a long extension handle was used to redistribute the solids closer to the floor drain. Nitric acid in the tank dissolved the solids and alleviated further slurry problems. 
1.21 Calciner Cell. Since most of the calciner cell equipment operates under "dry" conditions, special care was taken prior to use of decontaminants to prevent the formation of plugs in drain lines. Initially all lines leading to this equipment were thoroughly purged with air, and the solids transport system was operated until all possible solids material had been removed from the calciner and calciner cyclone. The first decontamination flush was introduced to the calciner vessel via the transport air line and was immediately allowed to drain to waste. This removed the bulk of the wet solids from the calciner vessel. Hot decontamination solutions were then added to the equipment through all the installed decontamination lines until the vessels were flooded. Decontamination from this point involves retaining the solution in the vessels at near boiling temperatures for a 24-hour period, draining the solution to waste, and repeating the refilling, heating, and draining sequences.

Twice during this processing campaign, as previously stated, it was necessary to clean large volumes of calcine product from the calciner cell floor. The original attempt at dissolving the solids with nitric acid proved to be slow and ineffective. The cleanup was accomplished in both cases by washing this material to a floor drain using long-handled scrapers and a fire hose, while working behind a shielding wall.

1.22 Off-Gas Cell. The bulk of the equipment and lines in the off-gas cell were decontaminated by circulating and replacing decontaminating solutions in the quench system. The exceptions were the off-gas reheater, $\mathrm{WC}-305$, the 10-inch off-gas line downstream of WC-305, and the adsorber silica gel transfer line. The 10-inch off-gas line and WC-305 proved to be most difficult to decontaminate. Decontamination was accomplished by flooding this equipment with decontamination solutions and maintaining heat in the solutions by adding steam through instrument pressure taps. The silica gel line was cleaned by adding decontamination solution to this line via a $1 / 4$-inch pressure tap. Cleanup was slow in all instances due to the limited volume of steam and decontaminants which could be added through the 1/4-inch lines.

1.23 Waste Hold Cell. The equipment in this cell, two vessels and assorted lines and valves, was deoontaminated using conventional decontamination techniques. Decontamination solutions were added via all possible piping. The solution was steam sparged, heated, recirculated, and finally transferred to the calciner vessel or the permanent storage tanks to aid in cleaning interconnecting lines.

1.24 Off-Gas Blower Cell. The maximum radiation levels in this cell during operation are in the 0.5 to $2.0 \mathrm{R} / \mathrm{hr}$ range. The main problem in decontaminating this cell and equipment is removal of external contaminants. Small leaks in piping and flanges allow condensed water vapor containing dissolved fission products from the off-gas stream to settle outside the blowers and piping. Internal decontamination is easily accomplished by flooding the hlowers with decunlamlnation solutions, but the external cleanup requires many man-hours of flushing and wiping of all surface areas with water, nitric acid, 4502 Turco, and Oxalic acid. 


\section{FACILITY INSPECTION AND REPAIRS}

In preparation for the third WCF processing campaign which started in August 1968, a number of components were inspected and/or repaired in order that extended operation, essentially with the zirconium fluoride waste, could be achieved. The inspections and repairs are itemized below.

(1) Quench pump WC-208-B (removed December 1967) -- The pin which prevents the impeller from unscrewing from the shaft had sheared, and the impeller dropped off the pump. The shaft was also damaged, but the rest of the components were in good condition. A new shaft was obtained and installed, and the pump was reinstalled in the tank and tested. Performance was satisfactory.

(2) Guench pump WC-208-A (removed at the completion of decontamination ) -- This pump operated throughout the zirconium portion of the run. The pump was disassembled and inspected. Localized areas of cast parts had suffered moderate to severe attack, but piping and piping welds were in good condition, and the pump was mechanically sound. The pump has been reassembled with new bearings, a new impeller, and a new impeller housing, and the pump has been reinstalled.

(3) The failure in the lubrication system for pump WC-208-B was in the return piping. Minor modifications have been made to the lubrication system to eliminate deficiencies.

(4) All the valves in the scrub lines to WC-107 and WC-907 were tested for bellows leaks. Two valves, RVC WC-107-1 and RVC WC-107-2, had leaks. The valves were removed, fitted with new bellows, and reinstalled. One of the valves, RVC WC-107-1, was fitted with one of the new larger and heavier bellows which were recently received. Both valves were in good condition except for the bellows leaks.

(5) A number of lines in the calciner cell were radiographed to check for erosion. The north and south product takeoff lines were both worn significantly at the point of the final bend which is inside the three-inch transport air line. The wear was not sufficient to warrant replacement of the section at this time, but it should be replaced after the next run. Other items which were radiographed but did not show any significant wear were:

(a) The jet, the venturi meter, and the slide valve in the transport air return line

(b) Selected parts of the product takeoff and solids sample lines

(c) The dipleg jet and the boron carbide sleeve.

(6) The throat section of the venturi scrubber was eroded extensively in four places just below the four scrub solution entry holes. The worst spot was well over half way through the wall of the pipe. 
(7) The throat section of the venturi scrubber was replaced with a large diameter section (4-inch ID versus $3-1 / 2$-inch ID). This should result in less pressure drop across the scrubber.

(8) Part of the interior of the de-entrainment separator, WC-908, was visible through the opening left by removal of the scrubber. A hole in the reducer was noted. The walls of the external housing were tested ultrasonically in a number of places, however, and no thin areas were found. No attempt was made to repair the interior section and none will be made until the next turnaround.

(9) Wall thicknesses were determined ultrasonically at a number of places on the 10-inch off-gas line and the 3-inch transport air line. At several bends on the transport air line, general thinning has occurred to the extent of 0.03 to 0.06 inch. The remaining wall thickness should be more than adequate for another run, however.

(10) The feed nozzle air caps were moderately worn, but not enough to alter spray characteristics significantly.

(11) Blowers WC-251-A, WC-251-B, WC-252, WC-250-A, and WC-250-B were inspected, overhauled, and tested. These blowers were in excellent condition.

(12) Cell exhaust blower WC-G-3302 failed during decontamination and was replaced with a spare.

(13) The in-cell portion of the calciner bed addition line was replaced and rerouted to minimize bends.

(14) The decontamination line to the 10-inch off-gas line between WC-910 and WC-305 was cut and capped. The line was rerouted to the top of WC-305, and a spray nozzle was added.

(15) All three feed nozzles were removed and replaced with spare units. line.

(16). The WCF service waste line was replaced with a new 8-inch Transite

(17) The water line to the top of WC-130 was cut, unplugged, and repaired. The plug consisted of hard water deposits.

(18) The silica gel transport air line (three-inch TAA 3004) was revised to eliminate a pocket in the line, and drain valve, RVC WC-102-6, was eliminated. A manual block valve was installed in the line where it passes through the off-gas cell. This valve will be closed during operation.

(19) A spare NaK pump was assembled and installed to replace the existing pump which was not in top condition because of minor short circuits across coil windings. 
(20) A hole was drilled in the flapper of the check valve in each of the scrub pump discharge lines. This will permit drainage of the lines back to the tank during turnarounds and will establish a continuous backflush of the idle pump.

\section{CONCLUSIONS}

The fluidized bed calcination of high-level radioactive waste solutions to granular solids has proven to be a safe, reliable, and economical means to manage wastes at ICPP. Operating performance has been excellent and the process has been shown to be adaptable to handle a wide variety of radioactive wastes, including all types of aluminum nitrate wastes and, most significantly, the corrosive zirconium fluoride wastes. Atmospheric pollution has been minimized by passing off-gas through a series of air cleaning devices (wet scrubbers, silica gel adsorbers, and filters) which reduce contaminants to negligible concentrations. 


\section{REFERENCES}

1. L. T. Lakey and J. R. Bower (eds.), ICPP Waste Calcining Facility Safety Analysis Report, IDO-14620 (December 1963).

2. J.C. Petrie et al, Fluidized Bed Calcination of Simulated Zirconium Fluoride Waste in Exploratory Pilot Test, IDO-14653 (July 1965).

3. R. E. Commander et al, Operation of the Waste Calcining Facility with Highly Radioactive Aqueous Waste Report of the First Processing Campaign, IDO-14662 (June 1966). 